\title{
SEISMOTECTONICS OF THE NEWPORT-INGLEWOOD FAULT ZONE IN THE LOS ANGELES BASIN, SOUTHERN CALIFORNIA
}

\author{
By Egill Hauksson
}

\begin{abstract}
The Newport-Inglewood fault zone (NIF) strikes northwest along the western margin of the Los Angeles basin in southern California. The seismicity (1973 to 1985) of $M_{L} \geqq 2.5$ that occurred within a $20-\mathrm{km}$-wide rectangle centered on the NIF extending from the Santa Monica fault in the north to Newport Beach in the south is analyzed. A simultaneous full inversion scheme (VELEST) is used to invert for hypocentral parameters, two velocity models, and a set of station delays. Arrival time data from three quarry blasts are included to stabilize the inversion. The first velocity model applies to stations located along the rim and outside the Los Angeles basin and is well resolved. It is almost identical to the starting model, which is the model routinely used by the CIT/USGS southern California seismic network for locating local earthquakes. The second velocity model applies to stations located within the Los Angeles basin. It shows significantly lower velocities down to depths of 12 to $16 \mathrm{~km}$, which is consistent with basement of Catalina Schist below the sediments in the western Los Angeles basin. The distribution of relocated hypocenters shows an improved correspondence to mapped surface traces of late Quaternary fault segments of the NIF. A diffuse trend of seismicity is observed along the Inglewood fault from the Dominguez Hills, across the Baldwin Hills to the Santa Monica fault in the north. The seismicity adjacent to Long Beach, however, is offset 4 to $5 \mathrm{~km}$ to the east, near the trace of the subsurface Los Alamitos fault. The depth distribution of earthquakes along the NIF shows clustering from 6 to $11 \mathrm{~km}$ depth, which is similar to average seismogenic depths in southern California. Thirty-nine singleevent focal mechanisms of small earthquakes (1977 to 1985) show mostly strikeslip faulting with some reverse faulting along the north segment (north of Dominguez Hills) and some normal faulting along the south segment (south of Dominguez Hills to Newport Beach). The results of an inversion of the focal mechanism data for orientations of the principal stress axes and their relative magnitudes indicate that the minimum principal stress is vertical along the north segment while the intermediate stress is vertical along the south segment. The maximum principal stress axis is oriented $10^{\circ}$ to $25^{\circ}$ east of north. Reverse faulting along the north segment indicates that a transition zone of mostly compressive deformation exists between the Los Angeles block and the Central Transverse Ranges.
\end{abstract}

\section{INTRODUCTION}

The Newport-Inglewood fault zone (NIF) forms the western margin of the Los Angeles basin in southern California. In the north, the NIF terminates at the eastnortheast trending Santa Monica fault along the southern margin of the Transverse Ranges. The NIF strikes northwest subparallel to the San Andreas fault and shows mostly a right-lateral strike-slip component of motion (Yerkes et al., 1965; Barrows, 1974). To the south, the NIF extends to Newport Beach and projects seaward into a system of faults having similar trends that can be traced more than $250 \mathrm{~km}$ south into Baja California (Ziony et al., 1974; Ziony and Yerkes, 1985). This study focuses on the Los Angeles basin (Figure 1), where the NIF is often characterized as a wrench fault, which includes a strike-slip fault at depth that folds and faults the overlying sediments (Wilcox et al., 1973). 


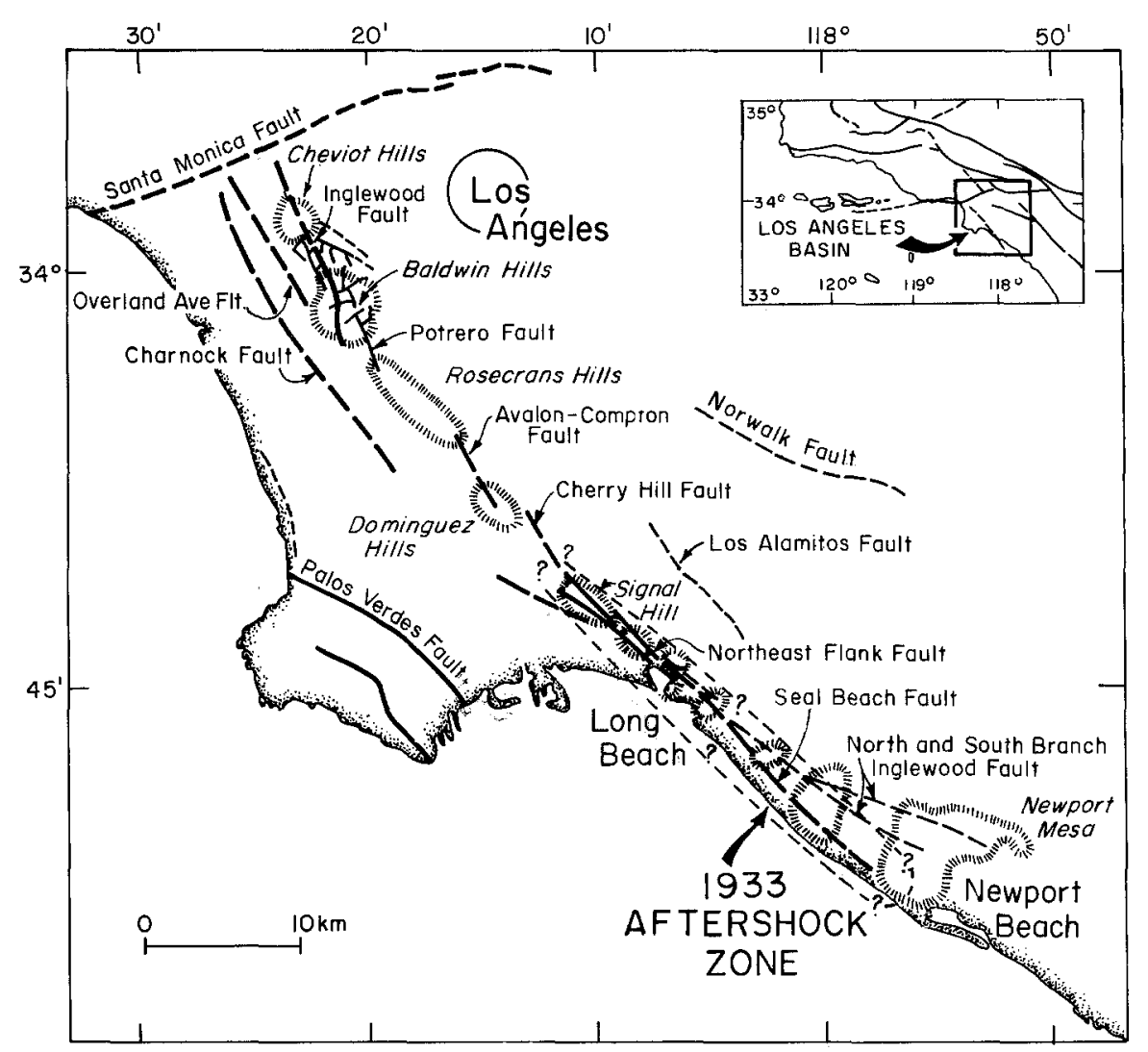

FIG. 1. Map of the Los Angeles basin showing the NIF and associated hills and mapped fault segments (Barrows, 1974). Inset shows the location of the Los Angeles basin. The approximate outline of the 1933 Long Beach $\left(M_{L}=6.3\right)$ aftershock zone is shown as a shaded area enclosed by a dashed line (Hileman et al., 1973).

At least five earthquakes of magnitude of 4.9 or larger have been associated with the NIF since 1920 (Barrows, 1974). The first reported damaging earthquake was the 1920 Inglewood earthquake $\left(M_{L}=4.9\right)$ that caused moderate damage in the town of Inglewood. Taber (1920) attributed the earthquake to fault slip on the NIF just west of the town. The largest instrumentally recorded earthquake that has occurred on the NIF is the 1933 Long Beach earthquake $\left(M_{L}=6.3\right)$ studied in detail by several investigators (e.g., Millikan, 1933; Wood, 1933; Benioff, 1938; Binder, 1952; Richter, 1958; Barrows, 1974). Wood (1933) calculated the epicenter as being $5.5 \mathrm{~km}$ southwest of Newport Beach. Benioff (1938) argued that the extent of seismogenic faulting reached from Newport Beach in the south to just north of Long Beach (Figure 1). Recently, Guptill and Heath (1981) found evidence of surface faulting along the North Branch of the NIF at west Newport Mesa. They suggest that the surface faulting is post-1920 and may have occurred during the 1933 earthquake. The 1933 earthquake was followed by a larger aftershock $\left(M_{L}=\right.$ 5.4) near Signal Hill on 2 October 1933. In 1941, two earthquakes of magnitude 5.0 and 5.4 caused damage in the Torrance-Gardena area (Richter, 1958). In part based on the reported seismicity, the NIF has been identified as an active fault capable of generating damaging earthquakes and has been declared a special study zone under the Alquist-Priolo Special Studies Zones Act of 1972 (Hart, 1980).

Since, 1973, high-gain, short-period seismic networks operated in the Los Angeles basin by the University of Southern California (USC) and near the rim and away 
from the basin by Caltech and the U.S. Geological Survey (CIT/USGS) have recorded a steady rate of small earthquakes in the Los Angeles basin (Teng et al., 1973; Norris et al., 1986). The primary focus of this paper is to carry out comprehensive analysis of these data for earthquakes that occurred along the NIF to determine: (1) the spatial distribution of epicenters as accurately as possible; (2) the lower seismogenic depth limit; and (3) the type of seismogenic faulting (e.g., strike-slip, reverse, or normal faulting). As a first step in studying seismogenic faults, accurate epicenters are needed to correlate the occurrence of small earthquakes with mapped geological faults. If small earthquakes are present, they can be used to establish spatial continuity of fault segments and the lower seimogenic depth limit. The fault length and width are parameters needed to estimate maximum likely earthquake magnitudes for future events (Bonilla et al., 1984). The patterns of faulting derived from focal mechanism data are useful for predicting the resulting ground motions from a potential damaging event (e.g., Spudich and Hartzell, 1985). Moreover, the focal mechanism data also provide information about the state of stress that is needed to understand crustal deformation near the plate boundary in southern California.

To mitigate earthquake hazards in the Los Angeles metropolitan area, detailed studies of the seismotectonic framework in the Los Angeles basin and surrounding regions are needed. This seismotectonic study is a first step and provides new information about fault segmentation, seismogenic depth limit, state of stress, and patterns of faulting along the NIF.

\section{Earthquake Data and Techniques}

Earthquake data. The seismicity reported in the CIT/USGS catalog during 1973 to 1985 in the Los Angeles basin and surrounding regions is shown in Figure 2. This
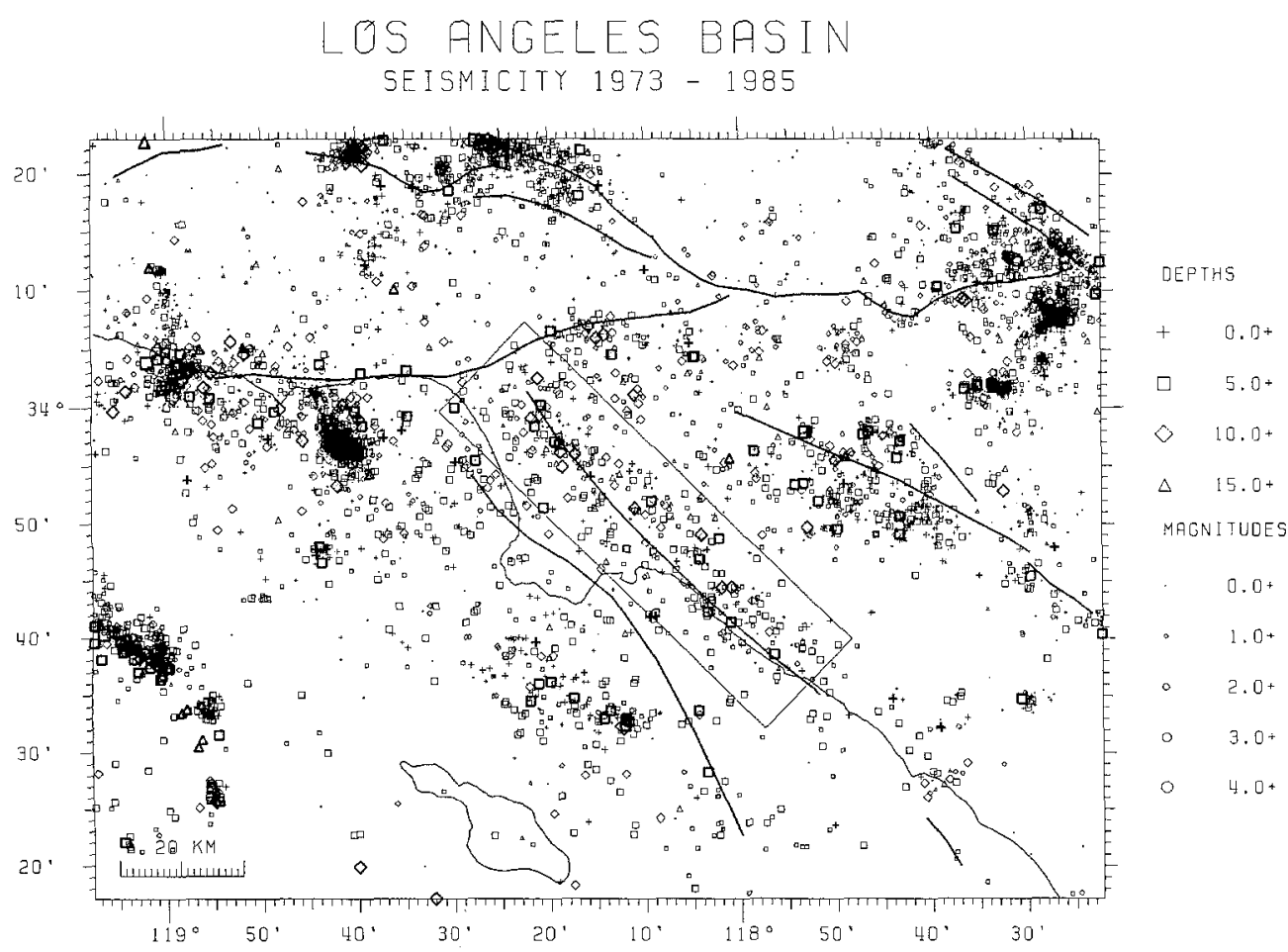

FIG. 2. Seismicity (1973 to 1985) of the Los Angeles basin and surrounding regions as reported by the CIT/USGS southern California Network. The symbol size and type are keyed to magnitudes and depth, respectively. The rectangle surrounding the NIF delineates the study zone. 
study includes 64 earthquakes of $M_{L} \geqq 2.5$ that occurred during 1973 to 1985 within a $20-\mathrm{km}$-wide and $72-\mathrm{km}$-long rectangle centered on the NIF (Figure 2). The rectangle that defines the study region was chosen to include earthquakes occurring along the main NIF trace as well as nearby branch faults located some distance away.

The rate of seismicity within the study zone is shown in Figure 3 . The largest earthquake during the last 13 yr occurred in January 1975 and had a magnitude of 3.8. Earthquakes of magnitude 2.5 or larger are in most cases felt in the densely populated Los Angeles basin. The rate of earthquake activity (Figure 3) shows that 2 to 9 small earthquakes near the NIF are felt each year.

A minimum magnitude cut-off value of 2.5 was chosen since the CIT/USGS earthquake catalog is complete to this magnitude level (Norris et al., 1986). Moreover, earthquakes of magnitude larger than 2.5 are in general well recorded by most stations in the southern California network, and hence high-quality focal mechanisms can be determined. In many instances, smaller earthquakes $\left(M_{L} \leqq 2.5\right)$ are not recorded by a sufficient number of stations to constrain their focal mechanisms. The smaller earthquakes are also less suitable for velocity inversions, since identification of the first arrival may be uncertain because the signal amplitude may be small or because the path attenuation is high in the basin.

Arrival time and first motion data of earthquakes recorded by both the USC and CIT/USGS networks were combined to obtain accurate locations and high-quality, single-event focal mechanisms.

The USC seismograms were rechecked to include as many first motions as possible and to include all the available $S$-wave arrivals as well. The USC seismograph stations located along the NIF provide necessary depth control and important

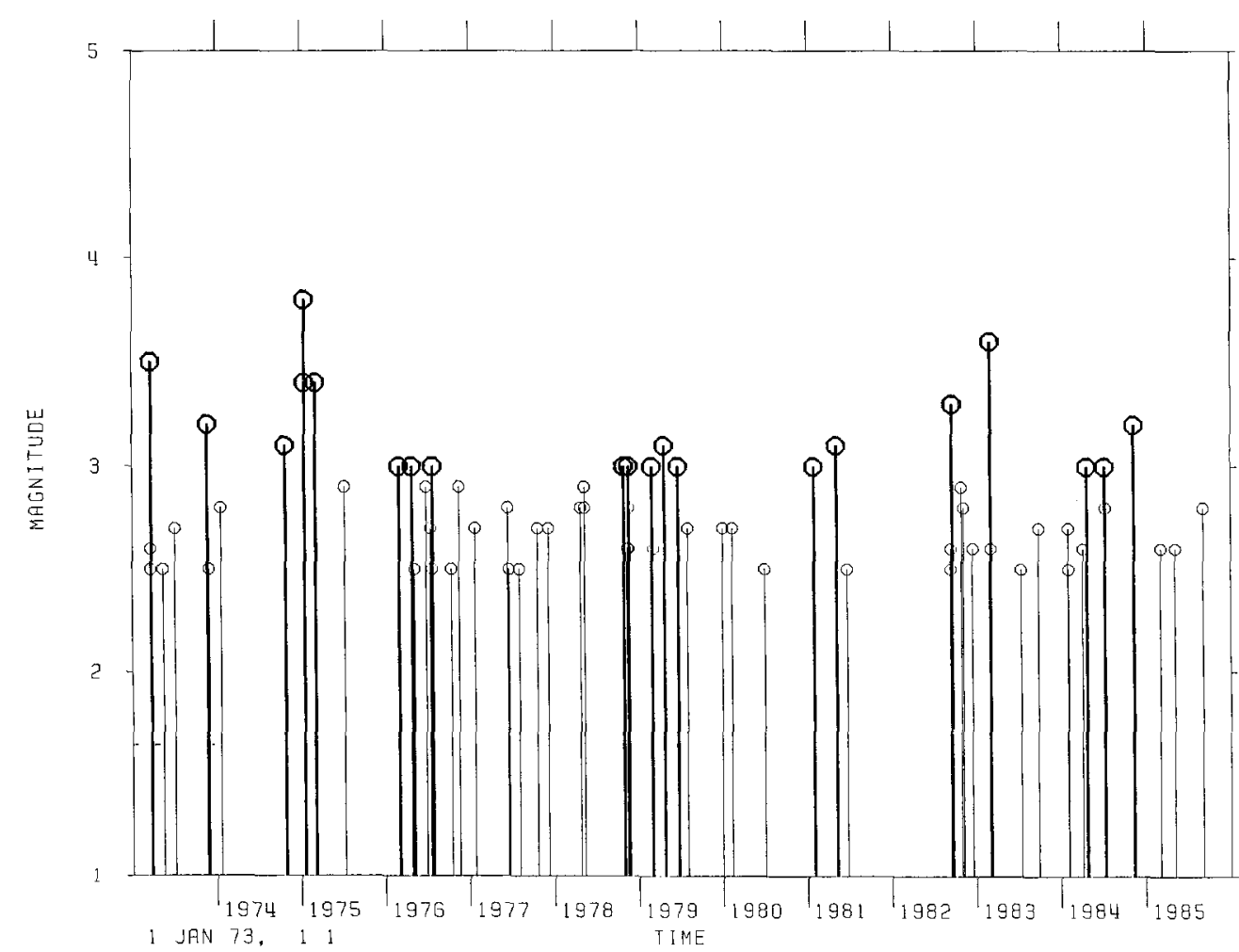

FIG. 3. Rate of seismicity of $M_{L} \geqq 2.5$ within the rectangle surrounding the NIF (shown in Figure 2). 
direct-ray first motions. The CIT/USGS stations located along the rim of the Los Angeles basin and away from the basin provide needed epicentral constraints as well as abundant first motions.

During the initial stages of this project, it became clear that often an earthquake of magnitude 2.5 to 3.5 only had 15 to 30 arrival times and first motions picked by the data analysts of the CIT/USGS network. At the same time, it was obvious that these earthquakes were being well recorded by at least 100 to 150 stations, so that the quality of the focal mechanisms can be increased significantly by including all the data. Hence, to optimize the quality of the focal mechanisms and to utilize the full capability of the network data, the necessary software to access the digital seismograms generated by either CEDAR or CUSP has been written. CEDAR and CUSP are the CIT/USGS earthquake data processing systems (Johnson, 1979, 1983). The CIT/USGS digital seismograms of earthquakes that occurred during 1977 to 1985 were analyzed to include all possible $P$ arrival times and first motions. The earthquake location algorithm (HYPOINVERSE) was used to calculate hypocenters as well as ray take-off angles and azimuths used in the determination of focal mechanisms (Klein, 1985). A computer algorithm (FPFIT) developed by Reasenberg and Oppenheimer (1985) was applied to determine the nodal planes of focal mechanisms using a grid search technique. Corrections of reversed station polarities were obtained from Norris et al. (1986).

The whole data set consisted of 64 earthquakes $\left(M_{L} \geqq 2.5\right)$ recorded during 1973 to 1985 . Because digital seismograms are available since 1977 , an attempt was made to determine focal mechanisms for all the earthquakes since 1977. Data were available for 41 earthquakes, and 39 focal mechanisms could be determined. The VELEST inversion included 40 of the 41 digitally recorded earthquakes. One event was excluded since it had an unconstrained depth. Earthquakes that had insufficient arrival time data available, and hence could not be relocated, are included in Table 2 with the original CIT/USGS hypocenter, flagged with a plus sign and not included in the figures.

Determination of velocity structure. To improve the quality and reliability of the earthquake hypocenters a simultaneous full inversion scheme called VELEST was used (Ellsworth, 1977; Roecker, 1981; Roecker and Ellsworth, 1978). This scheme that is in part derived from the procedure presented by Crosson (1976) includes both $P$ - and $S$-wave arrival times, which are important for the structurally complex Los Angeles basin. The scheme (VELEST) calculates a damped least-squares solution as adjustments to hypocentral parameters, velocity models, and station delays to minimize the rms residual of the travel-time residuals.

A network of 123 stations (Figure 4, A and B), 40 earthquakes, and three quarry blasts were used to invert for hypocenters, two velocity models, and a set of station delays. Arrival time data from three quarry blasts shown in Figure 4A stabilized the inversion. The SCI blast that was timed by Given and Koesterer (1983) was well recorded by stations all over southern California, including stations in the Los Angeles basin. The AZU blast was timed by USC. The AZU and COR blasts are smaller and not well recorded by stations in the Los Angeles basin, but well recorded by stations located to the north and east of the basin. The 40 earthquakes that were included in the inversion had good depth control with one or more stations at an epicentral distance less than the depth of the hypocenter. Each earthquake had 40 to 100 reported $P$ - and $S$-arrival times. The size of the station network is limited by the VELEST computer program to 127 stations. Hence, only stations at distances less than $200 \mathrm{~km}$ from the center of the study area were included. In addition, several stations in the distance range of 150 to $200 \mathrm{~km}$ that only had recorded less 


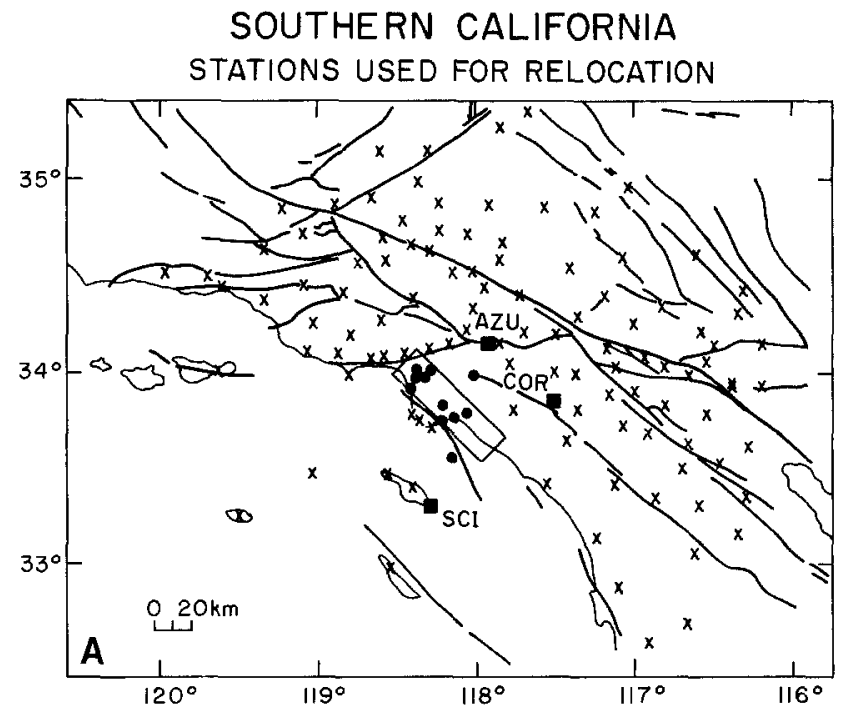

LOS ANGELES BASIN

STATIONS USED FOR RELOCATION

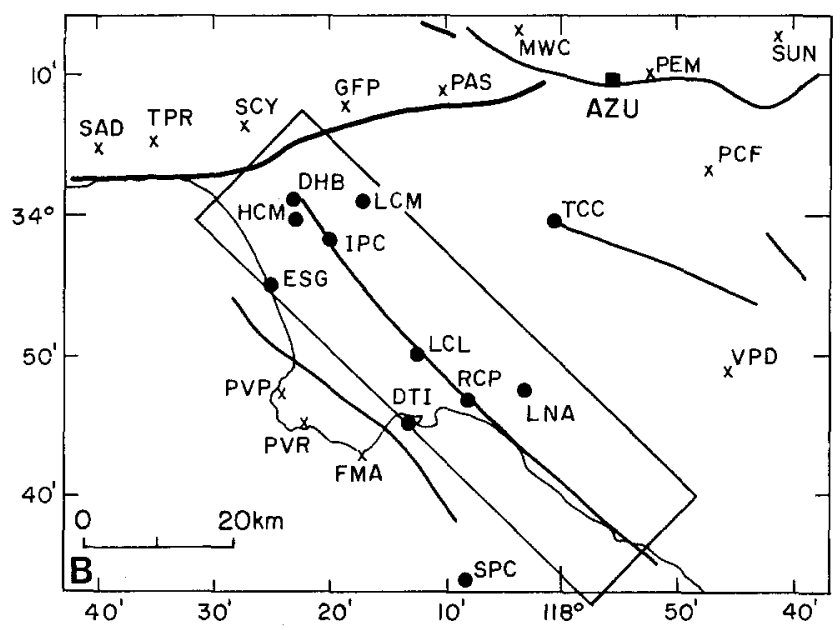

FIG. 4. (A) Map of seismograph stations in southern California used to relocate earthquakes near the NIF. Data from three quarry blasts (SCI, AZU, and COR) were also used in the VELEST inversion (see text). (B) Map of seismograph stations in the Los Angeles basin used to relocate earthquakes near the NIF. Stations marked by filled circles were assigned a slower velocity model (see Table 1). AZU is a quarry blast included in the VELEST inversion.

than five arrivals were removed from the station list to obtain a network of 123 stations for the inversion. The two starting models for the velocity structure are similar to the standard velocity model applied by the CIT/USGS network for routine earthquake locations (see Table 1). The standard velocity model is based on the velocity models derived by Hadley and Kanamori (1977). In this study, the depth to Moho in the starting model was changed from 37 to $32 \mathrm{~km}$, which is more consistent with the results of Hearn (1984). He used $P$-wave arrival times of local earthquakes and the time-term method to determine more accurately regional variations in the depth to Moho in southern California.

The VELEST scheme reduced the data variance from 0.16 to 0.05 while the rms travel-time residual is reduced from 0.40 to $0.18 \mathrm{sec}$. Since the VELEST scheme 
TABLE 1

\begin{tabular}{|c|c|c|c|c|c|}
\hline \multicolumn{3}{|c|}{ Southern California Model } & \multicolumn{3}{|c|}{ Los Angeles Basin Model } \\
\hline $\begin{array}{l}\text { Starting } \\
\text { Velocity } \\
(\mathrm{km} / \mathrm{sec})\end{array}$ & $\begin{array}{c}\text { Final } \\
\text { Velocity } \\
(\mathrm{km} / \mathrm{sec})\end{array}$ & $\begin{array}{c}\text { Depth to Top } \\
\text { of Layer } \\
\text { (km) }\end{array}$ & $\begin{array}{l}\text { Starting } \\
\text { Velocity } \\
(\mathbf{k m} / \mathrm{sec})\end{array}$ & $\begin{array}{c}\text { Final } \\
\text { Velocity } \\
(\mathrm{km} / \mathrm{sec})\end{array}$ & $\begin{array}{c}\text { Depth to Top } \\
\text { of Layer } \\
\text { (km) }\end{array}$ \\
\hline 5.5 & 5.52 & 0.0 & 4.5 & 4.11 & 0.0 \\
\hline 6.3 & 6.23 & 5.5 & 5.5 & 5.55 & 4.0 \\
\hline 6.7 & 6.62 & 16.0 & 6.3 & 5.73 & 5.5 \\
\hline \multirow[t]{2}{*}{7.8} & 7.73 & 32.0 & 6.7 & 6.66 & 16.0 \\
\hline & & & 7.8 & 7.80 & 32.0 \\
\hline
\end{tabular}

allows both $P$ and $S$ waves, as well as timed or untimed quarry blasts to be included, a stable iterative reduction of the data variance is obtained. The scheme was usually stopped when no further reduction in the data variance is accomplished (which is usually after nine iterations, where every third iteration included adjustments also to the velocity models and station delays).

Determination of stress. To obtain the orientation of the regional principal stress axes and the ratio of their lengths, the focal mechanism data were inverted with a technique developed by Michael (1984). His technique assumes that the regional stress field is a constant tensor, all the slip events are independent, and the magnitude of the tangential traction (or $|\bar{\tau}|$ ) applied to each fault plane is similar. The last assumption is equivalent to assuming that $|\bar{\tau}|=1$, since only relative stress magnitudes can be calculated. The inversion determines $|\bar{\tau}|$ applied to each fault plane by minimizing the quantity $|\bar{\tau}|-1$. Hence, the value of $|\bar{\tau}|$ must be similar but not necessarily equal to 1 . The inversion can also be described as minimizing the misfit angle between the direction of the shear stress on the fault plane and the observed slip direction on that plane determined from a focal mechanism. The inversion solves for the orientation of the three principal stress axes and a $\Phi$-value. The $\Phi$-value that is a measure of the relative magnitudes of the principal stresses is defined as:

$$
\Phi=\frac{S_{2}-S_{3}}{S_{1}-S_{3}}
$$

where $S_{1}, S_{2}$, and $S_{3}$ are the maximum, intermediate, and minimum principal compressive stresses. This inversion can only determine 4 of the 6 components of the stress tensor and hence can only be used to determine the deviatoric component of the stress tensor. The magnitude of stress and the isotropic component of the stress remain unknown.

To find the best-fitting deviatoric stress tensor, the misfit angle, $\beta$ (the angle between the direction of the tangential traction and the observed slip direction) and $|\bar{\tau}|$ are calculated. For a perfect data set, $\beta$ should be equal to 0 and $|\bar{\tau}|$ should be equal to 1 , but since the system of equations that are being solved is overdetermined, $\beta$ cannot be zero on all the fault planes, and $|\bar{\tau}|$ is usually only approximately equal to 1.

This technique gives similar results as the nonlinear scheme derived by Angelier et al. (1982) and Angelier (1984) and the grid-searching techniques used by Gephart and Forsyth (1984). To test various combinations of nodal planes, the data set was divided into six independent groups with only one nodal plane from each mechanism. 
Two groups (which consist of nodal planes selected to conform with the mapped geologic faults) are used to establish independently the state of stress along the north and south segments of the NIF. The north segment of the NIF is defined here as extending from Dominguez Hills north to the Santa Monica fault and the south segment as extending from Dominguez Hills south to Newport Beach (Figure 1).

\section{RESULTS}

Velocity structure. The starting and final $P$-wave velocity models (from the simultaneous inversion using arrival time data from local earthquakes and quarry blasts) for both southern California and the Los Angeles basin are shown in Figure 5 and Table 1 . The average velocity model for southern California is similar to the starting model based on the results of Hadley and Kanamori (1977). The sigma

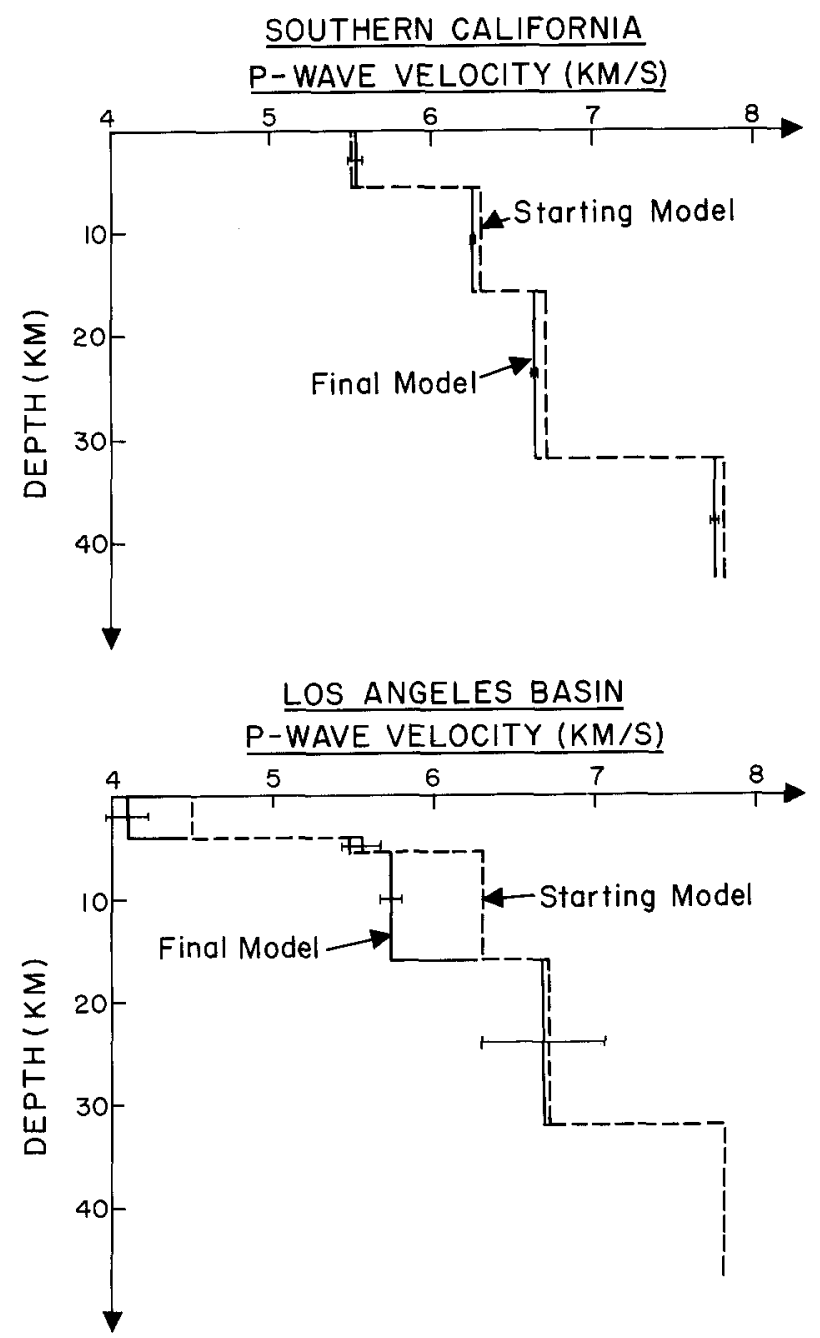

FrG. 5. (Top) Starting and final $P$-wave velocity model used for southern California in the VELEST inversion. Sigma error bars are also shown. (Bottom) Starting and final $P$-wave velocity model used for Los Angeles basin stations (shown as filled circles in Figure 4B). Sigma error bars are also shown. The error bars are large for layers that include only a few earthquakes. 
error bars are small, and the velocities are well resolved since many rays pass through each layer. This model therefore appears to be well suited for calculating ray paths traveling to the rim and away from the Los Angeles basin.

To simulate the low velocity basin sediments, seismograph stations in the Los Angeles basin were assigned a separate starting model that had a 4-km-thick top layer of low velocity $(4.5 \mathrm{~km} / \mathrm{sec}$ ) (Figure $4 \mathrm{~B}$ and Table 1 ). The velocity of $4.5 \mathrm{~km} /$ sec (for the uppermost $4 \mathrm{~km}$ of sediments) is somewhat higher than the average velocity of $2.9 \mathrm{~km} / \mathrm{sec}$ derived by Real (1977) from sonic logs taken in oil wells within the Los Angeles basin. The starting velocity of $4.5 \mathrm{~km} / \mathrm{sec}$ is preferred since most of the USC stations are either in 30- to 100-m deep boreholes or located on topographic escarpments. To smooth the velocity contrast to the third layer, a second $1.5-\mathrm{km}$-thick layer of $5.5 \mathrm{~km} / \mathrm{sec}$ velocity is added. The simultaneous inversion decreases the velocity of the three upper layers down to a depth of $16 \mathrm{~km}$, which is the depth of the deepest earthquakes. The most surprising result is the decrease of the velocity of the third layer from 6.3 to $5.7 \mathrm{~km} / \mathrm{sec}$. This decrease in velocity may be related to a smoothing effect, which attempts to assign an average low velocity to the whole ray path as opposed to concentrating the low velocity in the top layer. Such a smoothing effect (that is suggested by small positive station delays observed at the $1500 \mathrm{~m}$ deep borehole station DHB) may be related to the absence of hypocenters in the top layer. Even considering the effect of smoothing, however, the velocity of the third layer appears to be less than $6.3 \mathrm{~km} / \mathrm{sec}$ seen elsewhere in southern California. A value of 5.7 to $6.0 \mathrm{~km} / \mathrm{sec}$ would be consistent with a Catalina or Pelona Schist basement below the basin sediments (e.g., Malin et al., 1981). Hence, the velocity of the basement rocks below the basin sediments appears to be similar in magnitude to the basement velocities observed at the surface outside the basin.

To test the stability of the final model, a different starting model based on forward modeling of the SCI blast arrival time data (E. Hauksson, unpublished data) was used. In this case, a starting velocity of $6.3 \mathrm{~km} / \mathrm{sec}$ was also perturbed to a low final velocity of $5.8 \mathrm{~km} / \mathrm{sec}$ at depths between 4 and $12 \mathrm{~km}$. The large error bar on the fourth layer at depths of 16 to $32 \mathrm{~km}$ indicates that this layer is badly resolved, since only three hypocenters are located within it.

This Los Angeles basin model applies only to the western part of the basin, near the NIF and is only a preliminary attempt to determine the velocity of the basement rocks. The main usefulness of this model is to provide more realistic takeoff angles for rays terminating at stations in the basin, which are used for determining focal mechanisms.

Earthquake hypocenters. The initial hypocenters calculated using the Hadley and Kanamori (1977) velocity model without any station delays are shown in Figure 6. The epicenters scatter over a 10 - to $15-\mathrm{km}$-wide east-west zone and do not show an obvious correspondence with the surface trace of the NIF. Moreover, the increase in hypocentral depth down to 10 to $20 \mathrm{~km}$ between Inglewood and Long Beach could be attributed to an anomalous effect of the low velocity basin sediments (Figure 6).

To obtain the relocated hypocenters, the 40 digitally recorded earthquakes (1977 to 1985) were relocated using the full inversion scheme VELEST by Roecker and Ellsworth (1978). The two velocity models and the set of station delays obtained from VELEST were then used as input for HYPOINVERSE (Klein, 1985) to calculate final locations for the 64 earthquakes (Table 2).

To evaluate whether the relocated epicenters are systematically biased, the three 

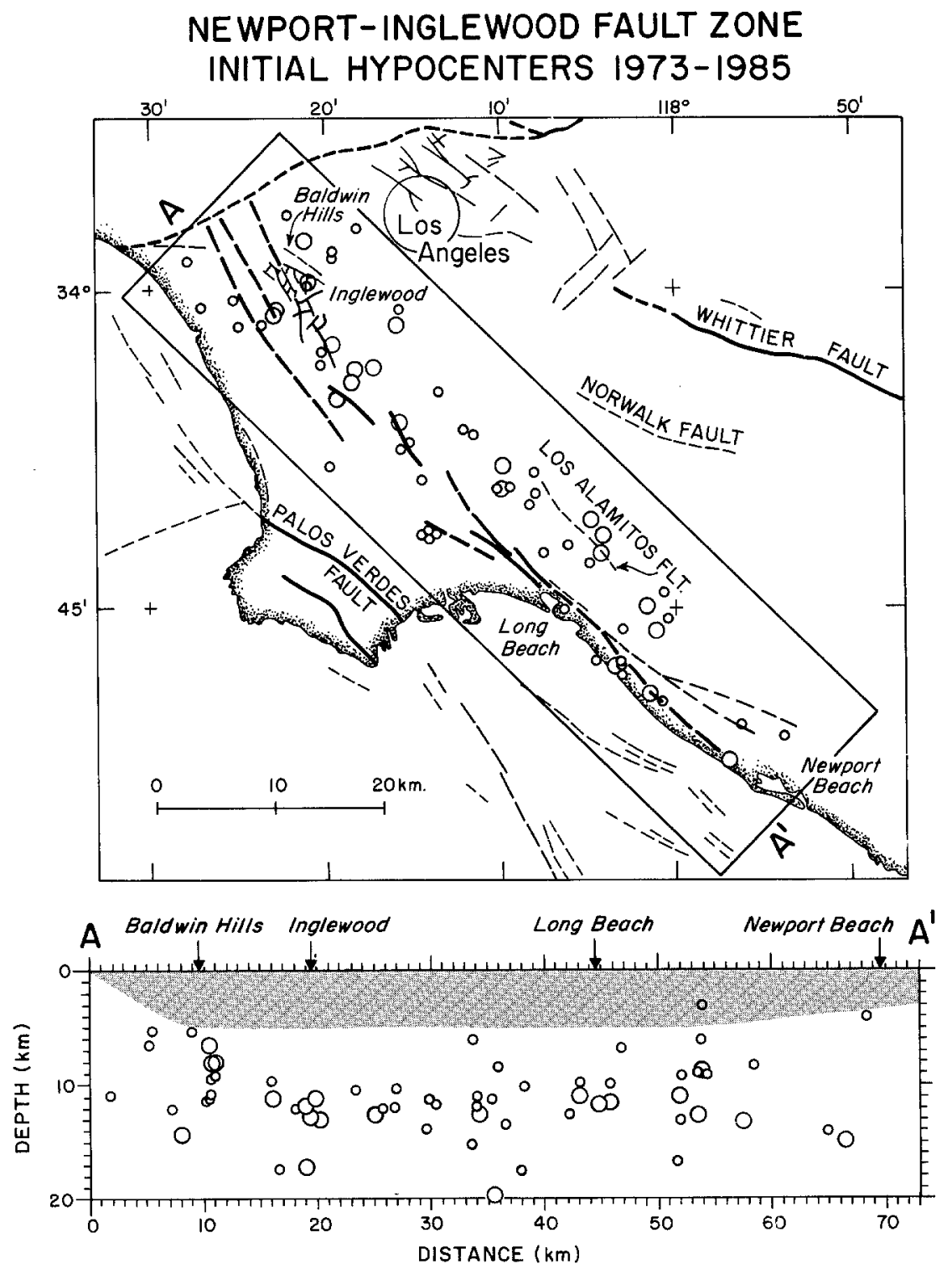

FIG. 6. (Top) Map of the Los Angeles basin and the NIF showing initial hypocenters (1973 to 1985) of magnitude $M_{L} \geqq 2.5$ determined with the starting velocity model for southern California and no station delays. (Bottom) Depth section $\left(A-A^{\prime}\right)$ showing the initial hypocenters along the NIF. The Los Angeles basin sediments near the NIF are shown as a shaded area.

quarry blasts were located using the standard model with no station delays and also with the two new velocity models and corresponding station delays. When using the original model, the SCI blast was mislocated $8 \mathrm{~km}$ to the south, and the COR blast was mislocated $4 \mathrm{~km}$ to the south, but the AZU blast was mislocated $1 \mathrm{~km}$ to the north. When using the VELEST models and delays, the SCI and COR blasts were only mislocated $2 \mathrm{~km}$ to the south, while the AZU blast remained at the same location. The velocity models and stations delays from VELEST thus appear to reduce significantly possible bias in the relocated epicenters to the south, which may be caused by high crustal velocities in the Peninsular Ranges (Hearn, 1984).

The distribution of relocated hypocenters shows an improved correspondence to 
mapped surface traces of late Quaternary fault segments of the NIF (Figure 7). Epicenters located to the east of the main fault trace have moved 2 to $3 \mathrm{~km}$ to the west while epicenters located on the fault trace remain unchanged. The epicentral distribution along the north segment of the NIF is still scattered and forms a diffuse trend that coincides with the fragmented surface traces of the NIF. Small clusters of epicenters near the subsurface Los Alamitos fault (which cuts lower Pleistocene but apparently not upper Pleistocene strata; Ziony et al., 1974) show less spatial scatter and form a northwest-striking linear zone of epicenters. The lack of seismic activity along the NIF in Long Beach may be related to the 1933 Long Beach $\left(M_{L}\right.$
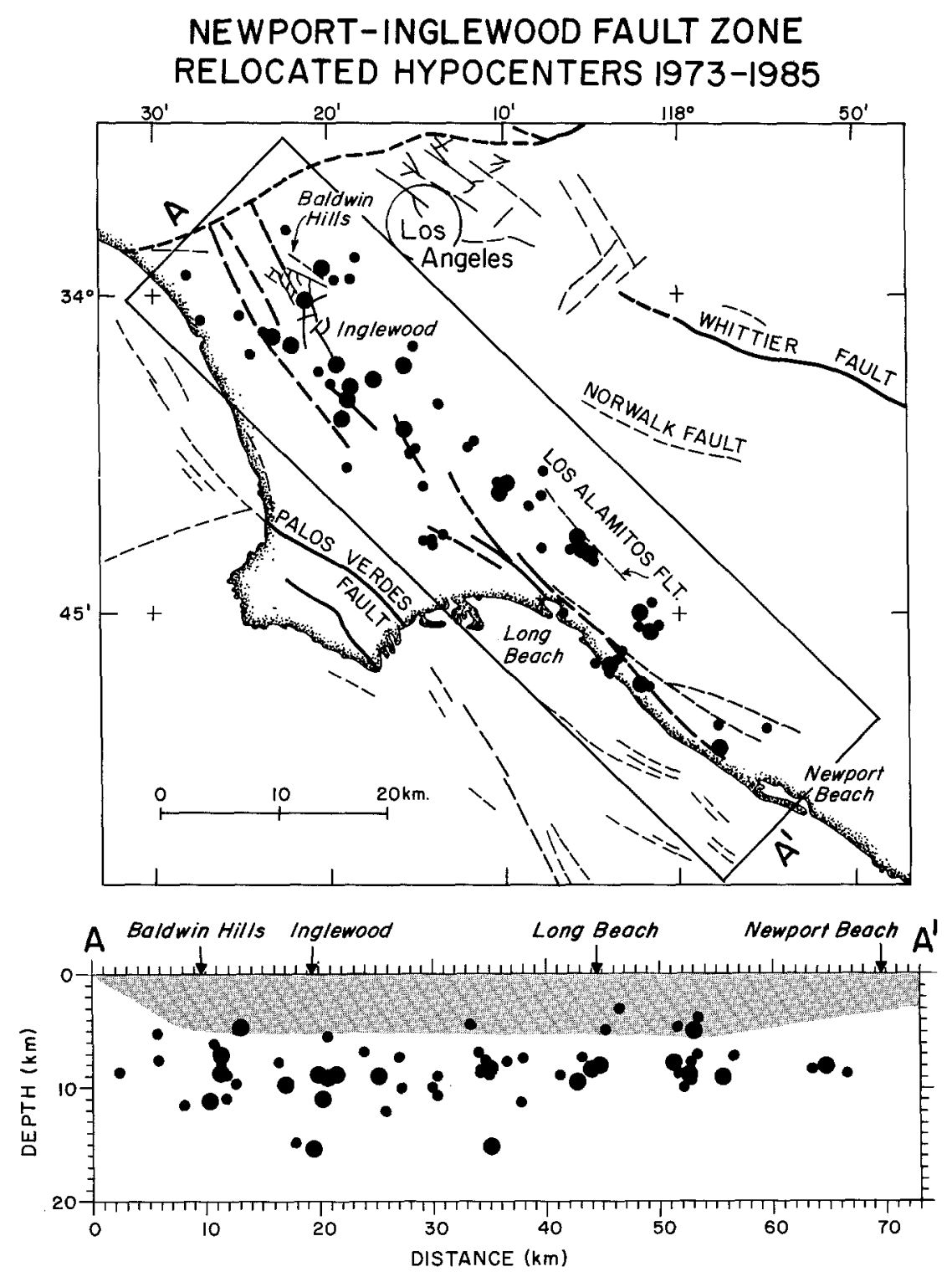

FIG. 7. (Top) Map of the Los Angeles basin and the NIF showing relocated hypocenters determined with two velocity models and a corresponding set of station delays. (Bottom) Depth section $\left(A-A^{\prime}\right)$ showing the relocated hypocenters along the NIF. The Los Angeles basin sediments are shown as a shaded area. 
TABLE 2

Hypocenters and Focal Mechanisms of Earthquakes $(M \geqq 2.5)$ aLONg the NIF (1973 TO 1985)

\begin{tabular}{|c|c|c|c|c|c|c|c|c|c|c|c|c|}
\hline \multirow[b]{2}{*}{ No.* } & \multirow[b]{2}{*}{$\begin{array}{c}\text { Date } \\
\text { (yr/mo/day) }\end{array}$} & \multirow[b]{2}{*}{ Time } & \multicolumn{2}{|c|}{ Location } & \multirow[b]{2}{*}{$\begin{array}{c}\text { Depth } \\
(\mathrm{km})\end{array}$} & \multirow[b]{2}{*}{ Magnitude } & \multirow[b]{2}{*}{$\begin{array}{l}\text { RMS } \\
\text { (sec) }\end{array}$} & \multirow[b]{2}{*}{$\begin{array}{l}\text { ERH } \\
(\mathbf{k m})\end{array}$} & \multirow[b]{2}{*}{$\begin{array}{l}\text { ERZ } \\
(\mathrm{km})\end{array}$} & \multicolumn{3}{|c|}{ Focal Mechanism } \\
\hline & & & $\begin{array}{l}\text { Latitude } \\
\left({ }^{\circ} \mathrm{N}\right)\end{array}$ & $\begin{array}{l}\text { Longitude } \\
\left({ }^{\circ} \mathrm{W}\right)\end{array}$ & & & & & & Ddir & Dip & Rake \\
\hline 1 & $85 / 09 / 03$ & 25854.4 & $34 \quad 2.9$ & 11822.3 & 7.5 & 2.8 & 0.17 & 0.2 & 0.3 & 235 & 50 & 160 \\
\hline 2 & $85 / 05 / 04$ & 81730.2 & 3350.9 & 11814.5 & 9.9 & 2.6 & 0.27 & 0.2 & 0.5 & 160 & 80 & 40 \\
\hline$\dagger$ & $85 / 03 / 02$ & 45348.7 & 3358.8 & 11827.2 & 5.2 & 2.6 & 0.24 & 0.2 & 0.5 & & & \\
\hline 3 & $84 / 11 / 08$ & 94332.5 & 3353.5 & 11815.6 & 8.9 & 3.2 & 0.28 & 0.2 & 0.6 & 150 & 75 & 20 \\
\hline 4 & $84 / 07 / 08$ & 13948.1 & 3342.0 & $118 \quad 3.8$ & 7.1 & 2.8 & 0.20 & 0.2 & 0.7 & 150 & 75 & 10 \\
\hline 5 & $84 / 07 / 08$ & 114117.8 & 3342.4 & $118 \quad 3.9$ & 8.9 & 3.0 & 0.23 & 0.2 & 0.5 & 150 & 80 & 10 \\
\hline 6 & $84 / 04 / 21$ & 115843.1 & 3338.5 & 11757.6 & 8.2 & 3.0 & 0.16 & 0.2 & 0.6 & 340 & 60 & 40 \\
\hline 7 & $84 / 04 / 03$ & 62639.7 & 3352.3 & 11815.3 & 10.0 & 2.6 & 0.18 & 0.2 & 0.4 & 150 & 90 & 10 \\
\hline$\dagger$ & $84 / 02 / 02$ & 71237.0 & 3352.6 & 11815.0 & 7.3 & 2.5 & 0.23 & 0.3 & 1.0 & & & \\
\hline 8 & $84 / 01 / 29$ & 201945.9 & 3342.9 & $118 \quad 3.2$ & 7.8 & 2.7 & 0.30 & 0.4 & 1.3 & 180 & 80 & -10 \\
\hline 9 & $84 / 01 / 29$ & 20625.3 & 3342.6 & $118 \quad 3.6$ & 9.2 & 2.7 & 0.28 & 0.3 & 1.0 & 85 & 90 & 170 \\
\hline 10 & $83 / 09 / 26$ & 4855.6 & 3354.8 & 11813.6 & 11.9 & 2.7 & 0.25 & 0.3 & 0.5 & 85 & 75 & -180 \\
\hline 11 & $83 / 07 / 13$ & 235357.8 & 3341.4 & $118 \quad 1.6$ & 7.2 & 2.5 & 0.22 & 0.3 & 1.7 & 170 & 80 & -10 \\
\hline 12 & $83 / 03 / 01$ & 201835.6 & 3355.9 & 11817.4 & 10.9 & 3.6 & 0.21 & 0.2 & 0.4 & 250 & 80 & 160 \\
\hline$\ddagger$ & $83 / 03 / 01$ & 7923.0 & 3357.4 & 11819.0 & 5.2 & 2.6 & & & & & & \\
\hline 13 & $82 / 12 / 13$ & $\begin{array}{lll}25 & 5 & 0.8\end{array}$ & 3342.5 & $118 \quad 4.7$ & 8.6 & 2.6 & 0.17 & 0.2 & 0.5 & 85 & 90 & -170 \\
\hline 14 & $82 / 11 / 06$ & 73732.2 & 3348.1 & 11813.9 & 8.4 & 2.8 & 0.18 & 0.1 & 0.5 & 90 & 75 & -170 \\
\hline 15 & $82 / 10 / 27$ & 102141.8 & 3352.7 & 11811.9 & 8.9 & 2.9 & 0.25 & 0.2 & 0.7 & 80 & 55 & -120 \\
\hline 16 & $82 / 09 / 17$ & 105750.1 & 3355.5 & 11818.6 & 15.2 & 3.3 & 0.17 & 0.2 & 0.2 & 225 & 50 & 90 \\
\hline 17 & $82 / 09 / 12$ & 155553.5 & 3348.1 & 11814.1 & 6.8 & 2.5 & 0.23 & 0.2 & 0.9 & 165 & 85 & -10 \\
\hline 18 & $82 / 09 / 11$ & 135531.5 & 3348.3 & 11814.5 & 4.4 & 2.6 & 0.23 & 0.2 & 0.8 & 200 & 35 & 100 \\
\hline 19 & $81 / 06 / 22$ & 18310.4 & 3344.9 & 1186.5 & 3.0 & & 0.35 & 0.3 & 0.4 & 10 & 90 & -10 \\
\hline 20 & $81 / 05 / 06$ & 55658.9 & 3344.0 & $\begin{array}{ll}118 & 1.7\end{array}$ & 5.0 & 3.1 & 0.17 & 0.2 & 0.5 & 90 & 55 & -140 \\
\hline $\mathrm{X} \S$ & $81 / 01 / 28$ & $\begin{array}{lll}4 & 0 & 16.3\end{array}$ & $34 \quad 1.1$ & 11820.3 & 11.5 & 3.0 & 0.18 & 0.3 & 0.5 & & & \\
\hline $\mathrm{X}$ & $80 / 07 / 02$ & 45331.1 & 3348.5 & 11813.5 & & 2.5 & 0.23 & 0.3 & 0.9 & & & \\
\hline 21 & $80 / 02 / 09$ & 91750.4 & 3347.9 & $118 \quad 6.2$ & 7.3 & 2.7 & 0.22 & 0.2 & 0.6 & 265 & 75 & 170 \\
\hline 22 & $79 / 12 / 31$ & 6340.0 & 3339.3 & 11754.9 & 8.7 & 2.7 & 0.23 & 0.3 & 0.8 & 90 & 50 & -130 \\
\hline 23 & $79 / 07 / 31$ & 125112.1 & 3350.5 & $118 \quad 7.8$ & 11.2 & 2.7 & 0.26 & 0.2 & 0.5 & 270 & 70 & 170 \\
\hline 24 & $79 / 06 / 20$ & 53035.4 & 3359.6 & 11821.2 & 7.2 & 3.0 & 0.26 & 0.3 & 0.5 & 140 & 65 & 80 \\
\hline 25 & $79 / 04 / 21$ & $\begin{array}{lll}6 & 0 & 38.2\end{array}$ & 3347.6 & $118 \quad 5.0$ & 8.0 & & 0.22 & 0.2 & 0.4 & 75 & 85 & -150 \\
\hline 26 & $79 / 03 / 05$ & 11039.6 & 3347.9 & $\begin{array}{ll}118 & 7.8\end{array}$ & 8.8 & 2.6 & 0.28 & 0.3 & 0.4 & 95 & 85 & -180 \\
\hline 27 & $79 / 02 / 27$ & 7738.5 & 3356.7 & 11819.5 & 9.7 & 3.0 & 0.17 & 0.2 & 0.3 & 135 & 60 & 20 \\
\hline 28 & $78 / 11 / 19$ & $18 \quad 0 \quad 16.4$ & 3350.9 & $118 \quad 9.9$ & 8.8 & 2.8 & 0.35 & 0.3 & 0.6 & 170 & 85 & 0 \\
\hline 29 & $78 / 11 / 19$ & 174056.1 & 3350.6 & 11810.2 & 15.1 & & 0.27 & 0.3 & 0.3 & 230 & 75 & -170 \\
\hline 30 & $78 / 11 / 19$ & $420 \quad 5.7$ & 3351.0 & 11810.1 & 7.5 & 2.6 & 0.30 & 0.2 & 0.6 & 170 & 80 & -10 \\
\hline $\mathrm{X}$ & $78 / 11 / 13$ & $\begin{array}{ll}0 & 629.2\end{array}$ & 3357.8 & 11815.2 & 9.0 & & 0.32 & 0.5 & 2.3 & & & \\
\hline $\mathrm{X}$ & $78 / 10 / 29$ & 8959.4 & 3354.0 & 11819.2 & 8.6 & 3.0 & 0.31 & 0.3 & 0.8 & & & \\
\hline 31 & $78 / 05 / 11$ & 175740.6 & $\begin{array}{ll}34 & 0.7\end{array}$ & 11828.0 & 8.7 & 2.8 & 0.24 & 0.3 & 0.6 & 330 & 70 & 10 \\
\hline 32 & $78 / 05 / 11$ & 54732.3 & 3359.5 & 11821.3 & 7.9 & 2.9 & 0.24 & 0.2 & 0.5 & 355 & 80 & 30 \\
\hline 33 & $78 / 04 / 26$ & 6821.6 & 3356.3 & 11820.4 & 7.7 & 2.8 & 0.29 & 0.3 & 0.8 & 140 & 45 & 90 \\
\hline 34 & $77 / 12 / 07$ & 154058.9 & 3347.3 & $118 \quad 4.8$ & 4.8 & 2.7 & 0.28 & 0.3 & 0.4 & 170 & 90 & 0 \\
\hline 35 & $77 / 10 / 20$ & $2014 \quad 0.3$ & 3344.3 & $118 \quad 1.0$ & 3.9 & 2.7 & 0.28 & 0.3 & 0.4 & 255 & 80 & -160 \\
\hline 36 & $77 / 08 / 03$ & 22833.6 & 3349.9 & $118 \quad 8.6$ & 7.3 & 2.5 & 0.25 & 0.2 & 0.7 & 135 & 40 & -70 \\
\hline 37 & $77 / 06 / 20$ & $1833 \quad 0.1$ & $34 \quad 0.6$ & 11818.8 & 9.6 & 2.5 & 0.35 & 0.3 & 0.5 & 180 & 70 & 60 \\
\hline 38 & $77 / 06 / 14$ & 15633.5 & $34 \quad 0.6$ & 11819.5 & 9.0 & 2.8 & 0.26 & 0.2 & 0.5 & 160 & 75 & -20 \\
\hline 39 & $77 / 01 / 24$ & 113516.7 & 3353.0 & 11811.6 & 10.6 & 2.7 & 0.23 & 0.2 & 0.6 & 110 & 50 & -80 \\
\hline $\mathrm{X}$ & & $128 \quad 4.0$ & 3355.7 & 11819.7 & 14.9 & 2.9 & 0.23 & 0.3 & 0.5 & & & \\
\hline $\mathrm{X}$ & $76 / 10 / 15$ & 155639.2 & 3345.4 & $\begin{array}{ll}118 & 1.3\end{array}$ & 4.6 & 2.5 & 0.30 & 0.4 & 1.1 & & & \\
\hline
\end{tabular}


TABLE 2-Continued

\begin{tabular}{|c|c|c|c|c|c|c|c|c|c|c|c|c|}
\hline \multirow[b]{2}{*}{ No. ${ }^{*}$} & \multirow{2}{*}{$\begin{array}{c}\text { Date } \\
\text { (yr/mo/day) }\end{array}$} & \multirow[b]{2}{*}{ Time } & \multicolumn{2}{|c|}{ Location } & \multirow{2}{*}{$\begin{array}{l}\text { Depth } \\
(\mathbf{k m})\end{array}$} & \multirow[b]{2}{*}{ Magnitude } & \multirow{2}{*}{$\begin{array}{l}\mathrm{RMS} \\
(\mathrm{sec})\end{array}$} & \multirow{2}{*}{$\begin{array}{l}\text { ERH } \\
(\mathrm{km})\end{array}$} & \multirow[b]{2}{*}{$\begin{array}{l}\text { ERZ } \\
(\mathrm{km})\end{array}$} & \multicolumn{3}{|c|}{ Focal Mechanism } \\
\hline & & & $\begin{array}{l}\text { Latitude } \\
\left({ }^{\circ} \mathrm{N}\right)\end{array}$ & $\begin{array}{l}\text { Longitude } \\
\left({ }^{\circ} \mathrm{W}\right)\end{array}$ & & & & & & Ddir & Dip & Rake \\
\hline $\mathrm{X}$ & $76 / 07 / 23$ & 205355.7 & 3351.0 & $\begin{array}{ll}118 & 9.8\end{array}$ & 8.3 & 3.0 & 0.23 & 0.3 & 0.7 & & & \\
\hline$\dot{\ddagger}$ & $76 / 07 / 22$ & 114132.1 & 3356.2 & 11815.6 & 8.0 & 2.5 & & & & & & \\
\hline$\ddagger$ & $76 / 07 / 15$ & 22739.9 & 3351.6 & $118 \quad 7.9$ & 11.3 & 2.7 & & & & & & \\
\hline $\mathrm{X}$ & $76 / 06 / 27$ & 221136.3 & $34 \quad 1.7$ & 11818.4 & 10.9 & 2.9 & 0.28 & 0.4 & 0.7 & & & \\
\hline$\neq$ & $76 / 05 / 07$ & $\begin{array}{lll}5 & 3 & 3.2\end{array}$ & 3337.4 & 11755.2 & 0.9 & 2.5 & & & & & & \\
\hline $\mathrm{x}$ & $76 / 04 / 25$ & 17518.3 & 3344.9 & $118 \quad 2.2$ & 7.9 & 3.0 & 0.37 & 0.5 & 1.3 & & & \\
\hline $\mathrm{X}$ & $76 / 02 / 29$ & 13126.0 & 3341.6 & $\begin{array}{ll}118 & 2.2\end{array}$ & 9.1 & 3.0 & 0.24 & 0.4 & 0.9 & & & \\
\hline $\mathrm{X}$ & $75 / 07 / 07$ & 13598.6 & 3357.2 & 11824.3 & 8.8 & 2.9 & 0.17 & 0.4 & 0.6 & & & \\
\hline $\mathrm{X}$ & $75 / 03 / 03$ & 153444.8 & 3355.0 & 11818.8 & 8.8 & 3.4 & 0.20 & 0.3 & 1.0 & & & \\
\hline $\mathrm{X}$ & $75 / 01 / 14$ & 75841.2 & 3347.9 & $118 \quad 5.3$ & 8.4 & 3.4 & 0.27 & 0.4 & 0.9 & & & \\
\hline $\mathrm{X}$ & $75 / 01 / 13$ & 112149.8 & 3348.5 & $118 \quad 5.7$ & 9.5 & 3.8 & 0.35 & 0.6 & 1.3 & & & \\
\hline $\mathrm{X}$ & $74 / 10 / 22$ & 121338.8 & 3358.0 & 11823.2 & 8.8 & 3.1 & 0.30 & 0.6 & 0.9 & & & \\
\hline $\mathrm{X}$ & $74 / 01 / 07$ & 83051.3 & 3351.8 & 11818.9 & 6.8 & 2.8 & 0.26 & 0.5 & 1.9 & & & \\
\hline $\mathrm{X}$ & $73 / 11 / 29$ & 112519.4 & 3358.9 & 11825.0 & 11.5 & 2.5 & 0.17 & 0.4 & 0.3 & & & \\
\hline $\mathrm{X}$ & $73 / 11 / 18$ & 72959.8 & 3357.5 & 11822.0 & 4.7 & 3.2 & 0.26 & 0.5 & 0.6 & & & \\
\hline $\mathrm{X}$ & $73 / 07 / 03$ & 84416.1 & 3344.2 & $\begin{array}{ll}118 \quad 2.2 \\
\end{array}$ & 9.9 & 2.7 & 0.29 & 0.5 & 1.3 & & & \\
\hline $\mathrm{X}$ & $73 / 07 / 01$ & 214419.1 & 3351.6 & $118 \quad 8.3$ & 8.9 & 2.7 & 0.27 & 0.4 & 1.2 & & & \\
\hline $\mathrm{X}$ & $73 / 05 / 13$ & 15234.6 & 3358.3 & 11823.3 & 6.1 & 2.5 & 0.55 & 1.1 & 0.9 & & & \\
\hline $\mathrm{X}$ & $73 / 03 / 21$ & 41150.7 & 3356.6 & 11815.6 & 8.8 & 3.5 & 0.54 & 1.1 & 4.0 & & & \\
\hline 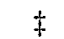 & $73 / 03 / 19$ & 195819.0 & 3338.7 & $118 \quad 3.2$ & 8.0 & 2.5 & & & & & & \\
\hline $\mathrm{X}$ & $73 / 03 / 17$ & 95325.0 & 3339.4 & 11757.6 & 8.3 & 2.6 & 0.43 & 1.0 & 2.4 & & & \\
\hline
\end{tabular}

Latitude in degrees and minutes; longitude in degrees and minutes; local magnitude from CIT/USGS catalog; RMS = root mean square travel-time residual in seconds; $\mathrm{ERH}=$ horizontal error in kilometers; $\mathrm{ERZ}=$ depth error in kilometers; Ddir $=$ dip direction in degrees; $\mathrm{Dip}=$ dip in degrees; and Rake = rake in degrees.

* Number refers to focal mechanisms in Figures 9 and 10.

$\uparrow$ Focal mechanism cannot be determined.

$\leftarrow$ Location from Caltech Catalog, included for completeness.

$\S \mathrm{X}=$ only existing CIT + USC arrival-time data used.

$=6.3$ ) earthquake that ruptured the southern section of the NIF. The southern half of the 1933 rupture zone from Huntington Beach to Newport Beach, however, appears to be seismically active.

The depth distribution of the relocated hypocenters is more uniform and the exceptionally deep hypocenters between Inglewood and Long Beach have moved up to shallower depths (Figure 7). The depth distribution of hypocenters is no longer biased by the low velocity sediments of the basin. The histogram of earthquake depths in Figure 8 shows that earthquake depths along the NIF are similar to the average depths of small earthquakes in southern California (e.g., Sibson, 1984). Most of the seismicity is occurring below the basin sediments between depths of 7 and $10 \mathrm{~km}$. The lack of shallow seismicity $(<5 \mathrm{~km})$ indicates that faults in the basin sediments were mostly aseismic during the 1973 to 1985 period. Moreover, three events of a total of 64 events are located at a depth of $15 \mathrm{~km}$, indicating minor seismic activity in the upper part of the lower crust. Since only a few deep events $(\sim 15 \mathrm{~km})$ are observed, the depth distribution suggests that the lower seismogenic depth limit or the brittle ductile transition zone (at 11 to $13 \mathrm{~km}$ depth) in the 
western part of the Los Angeles basin is not suppressed by the basin sediments. This is also consistent with the average heat flow of the northern Peninsular Ranges and the Los Angeles basin (Lachenbruch et al., 1985).

Focal mechanisms and state of stress. Lower hemisphere focal mechanisms were determined for 39 events (1977 to 1985) of magnitude 2.5 to 3.6 (Figure 9 and Table 2). The grid searching algorithm (FPFIT) by Reasenberg and Oppenheimer (1985) was used to determine nodal planes, and in general, nodal planes are constrained to $\pm 5^{\circ}$. Duplicate solutions found by the grid searching algorithm are shown in Figure 9 flagged with a star. The focal mechanisms of two earthquakes could not be constrained either because their depth was too shallow or a sufficient number of first motions was not available (Table 2).

The majority of the focal mechanisms in Figure 10 show strike-slip faulting with one nodal plane striking subparallel to the strike of the NIF. The orientation of the northerly striking nodal planes is more consistent with the strike of the main fault trace for the larger and deeper events than for the shallow and smaller events. These smaller events tend to have an almost pure north-south strike. Yeats (1973) points out that a northerly basement anisotropy exists in the western Los Angeles basement rocks. This anisotropy may be responsible for the northerly trending prelate Pliocene faults mapped in the oil fields along the south segment of the NIF. Hence, the orientation of the north-south nodal plane of most of the strike-slip mechanisms may be controlled by the existing basement anisotropy.

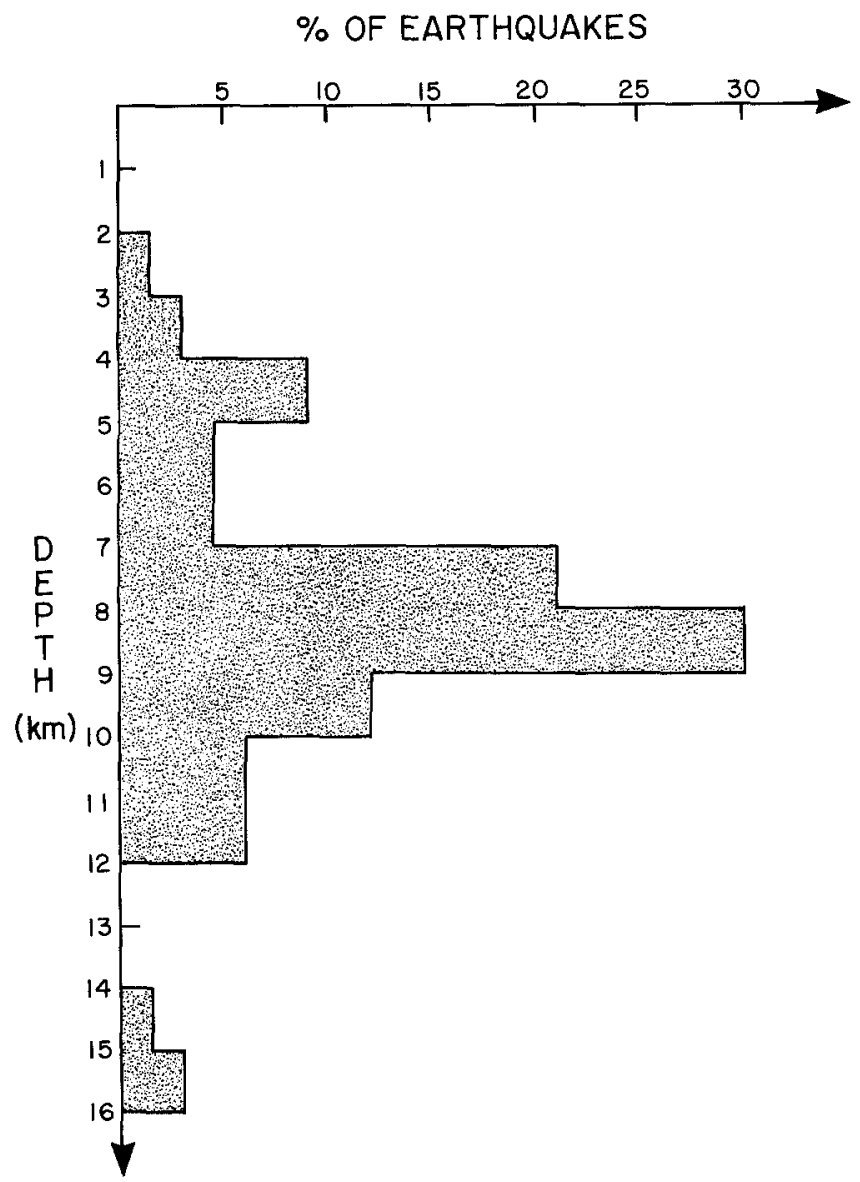

FrG. 8. Depth distribution of the relocated hypocenters located near the NIF (see also Figure 7). 
Along the north segment of the NIF, six focal mechanisms show reverse faulting while seven mechanisms show strike-slip faulting. On the other hand, along the south segment of the NIF, a mixture of normal and strike-slip faulting is observed with only a single reverse mechanism (Figure 10). The focal mechanisms thus document a change in state of stress and pattern of seismogenic faulting from north to south. The north segment is characterized by compression while the south segment is characterized by tension.

To quantify the observed change in state of stress and associated pattern of faulting, the focal mechanism data were inverted for the stress field that caused the faulting using a technique developed by Michael (1984). The input data for the inversion and the respective results are shown in Figure 11. Initially, all nodal planes from all of the focal mechanisms were included in the inversion. In this case, the orientations of the principal stress axes are reliable but the confidence limits may be underestimated (personal communication, A. J. Michael, 1986). The maximum principal stress is horizontal and has an azimuth of $25^{\circ}$ east of north, while the intermediate principal stress is vertical.

To test if the state of stress varies along the fault from north to south, the data from the north and south segments were separated. For each segment, one nodal plane was chosen from each focal mechanism on the basis of geology. The following planes were chosen: (1) northerly striking nodal planes from strike-slip mechanisms, which are subparallel to the NIF; (2) north-dipping nodal planes from reverse mechanisms, which are consistent with reverse faulting along the south boundary of the Santa Monica Mountains; and (3) east-dipping nodal planes from normal mechanisms, which indicate down-faulting of the Los Angeles basin.

The first group included 13 north-striking and -dipping nodal planes (one plane from each mechanism) along the north segment of the fault, north of Dominguez Hills. The results of the inversion for the north segment show that the maximum and intermediate principal stress axes are horizontal, and the maximum principal stress strikes $\mathrm{N} 13^{\circ} \mathrm{E}$. The $\phi$-value $(0.20 \pm 0.09)$ (the measure of the relative sizes of the principal stresses) indicates that the magnitude of the intermediate and mini-

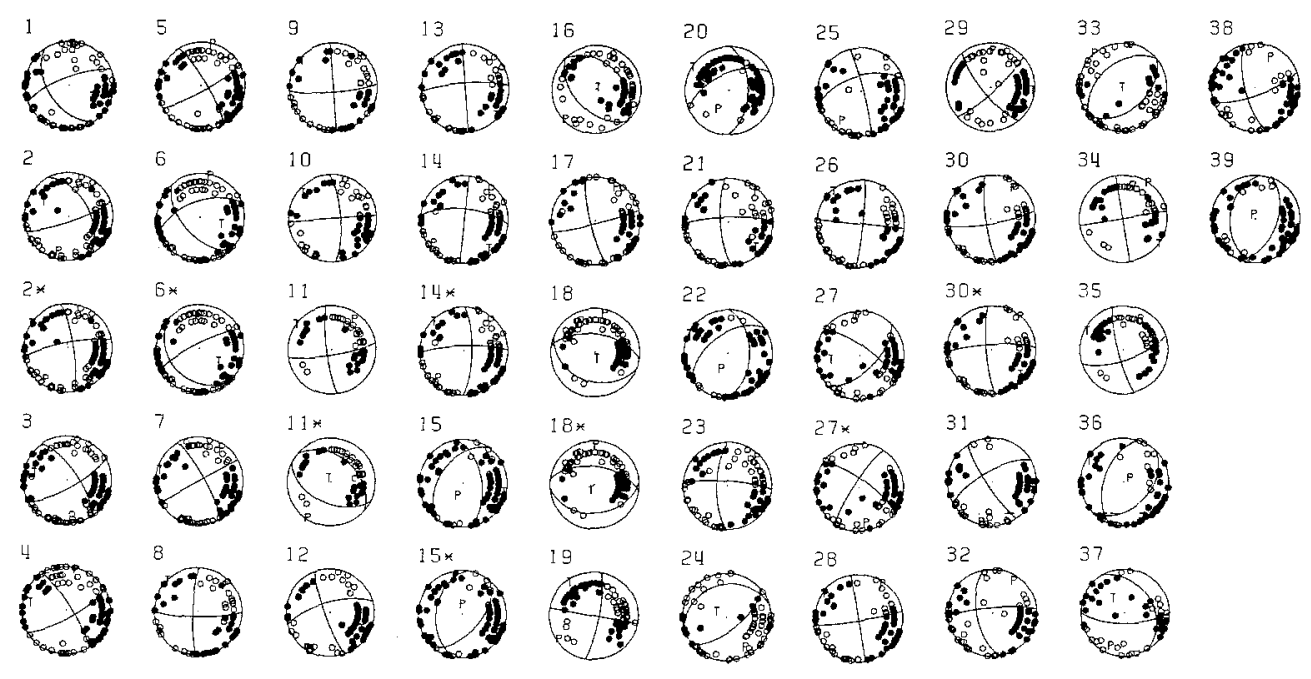

FIG. 9. Lower hemisphere (single event) focal mechanisms of earthquakes $\left(M_{L} \geqq 2.5\right)$ near the NIF (1973 to 1985). Open circle symbols indicate dilatational first motion, and closed circle symbols indicate compressional first motion. $P$ and $T$ axes are also shown. Numbers in the upper left-hand corner refer to Table 2. Duplicate solutions for the same earthquake are flagged with a star. 


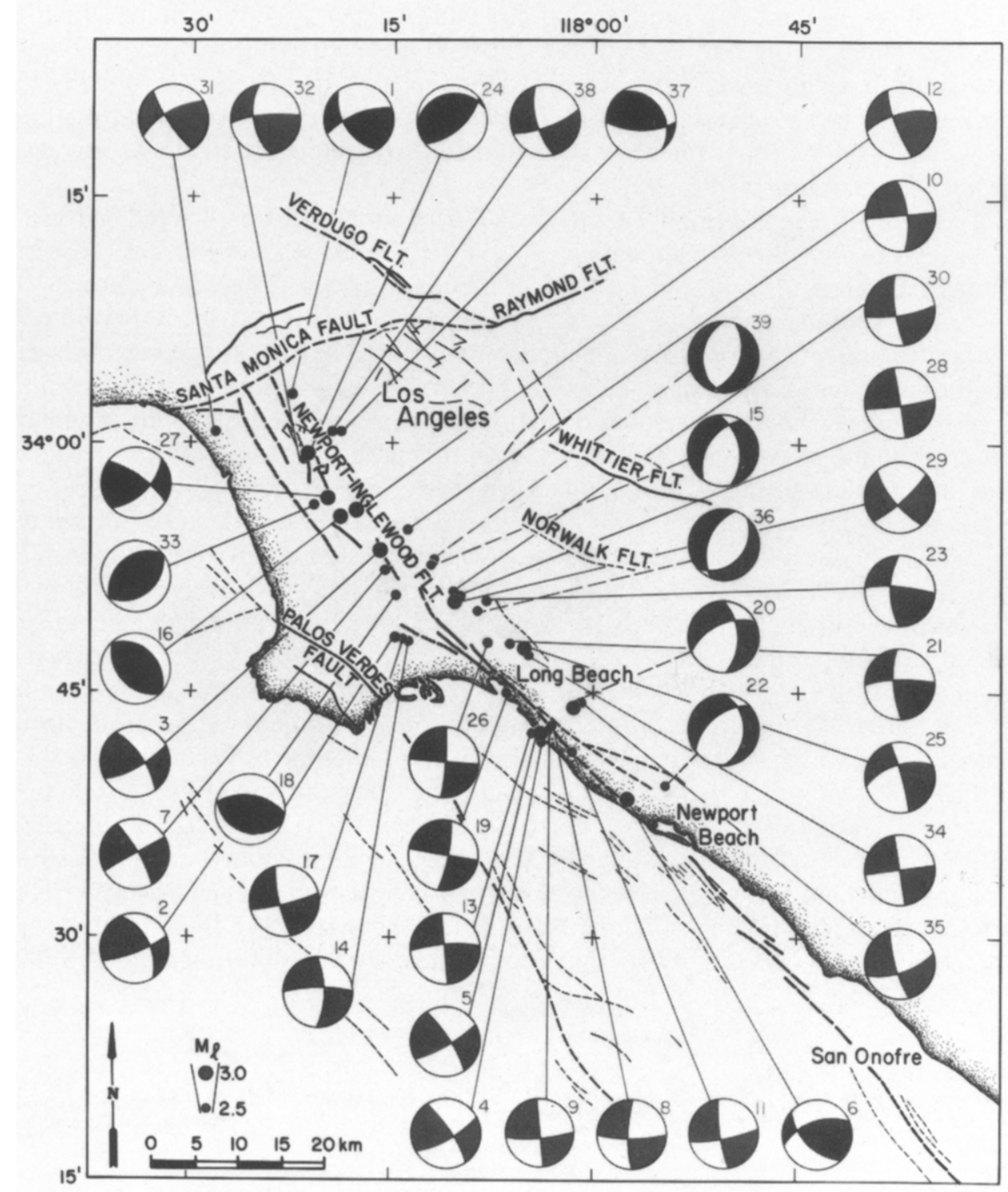

FIG. 10. Lower hemisphere (single event) focal mechanisms of earthquakes $\left(M_{L} \geqq 2.5\right)$ near the NIF (1973 to 1985). Numbers in the upper right-hand corner refer to Table 2.

mum stresses is very similar. Hence, small heterogeneities in the local stress field can change the style of seismogenic faulting from strike-slip to reverse or vice versa.

The second group included 26 north-striking and east-dipping nodal planes (one plane from each mechanism) along the south segment of the fault, extending from Dominguez Hills to Newport Beach. The results of inverting the second data set show that the maximum principal stress has an azimuth of $23^{\circ}$, and the intermediate stress axis is vertical along the south segment. Moreover, the $\phi$-value $(0.57 \pm 0.10)$ is significantly different, indicating that the principal stress axes have different 


\section{NEWPORT - INGLEWOOD FAULT}

(A) ALL NODAL PLANES
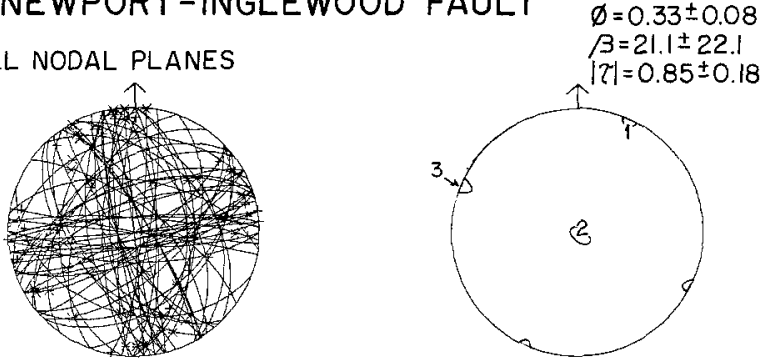

(B) NORTH STRIKING \& DIPPING NODAL PLANES ALONG THE NORTH SEGMENT
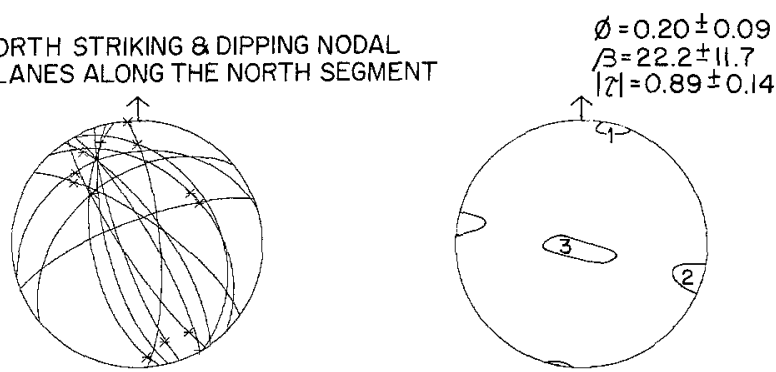

(C) NORTH STRIKING \& DIPPING NODAL PLANES ALONG THE SOUTH SEGMENT
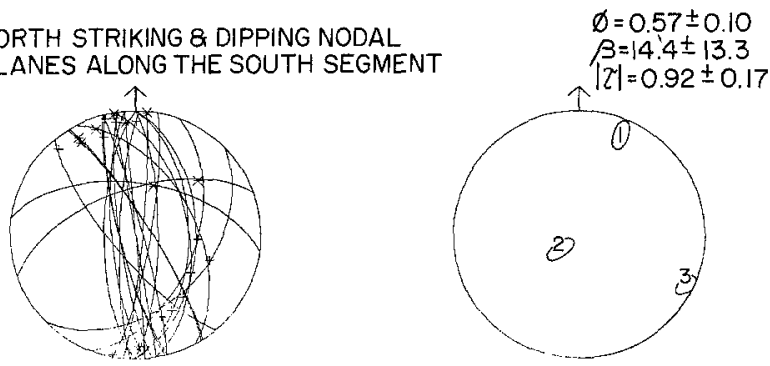

FIG. 11. Data and results of the stress inversion. (A) Lower hemisphere projection of all nodal planes from all of the focal mechanisms that are included in the inversion are shown to the left. Location of the slip vector is shown on each nodal plane as a plus symbol (with a normal component) or a star (with a thrust component). The results of the inversion are shown to the right as: (1) orientations of the principal stress axes; the contours indicate 95 per cent confidence areas for the principal stress axes; (2) $\phi$-value that is a measure of the relative sizes of the principal stresses; (3) $\beta$-value that is the average misfit angle between the predicted tangential traction and observed slip direction; and (4) $|\tau|$-value that is the average magnitude of the tangential traction. (B) North-striking and -dipping nodal planes along the north segment (north of Dominguez Hills) of the NIF that are included in the inversion are shown to the left, and the results are shown to the right. (C) North-striking and east-dipping nodal planes along the south segment (south of Dominguez Hills) of the NIF that are included in the inversion are shown to the left, and the results are shown to the right.

magnitudes. The $\beta$-value that is the average misfit angle between the predicted tangential traction and observed slip direction shows a better fit for the second group than for the first group. This variation in the average misfit angle may be caused by either a small data set or a more homogeneous stress field along the south segment.

To confirm the results shown in Figure 11 for the two north and south data groups, several other groups of nodal planes (e.g., west-striking and south-dipping or north-striking and south-dipping nodal planes) were also inverted. Four different combinations of fault planes all provided similar results within the calculated confidence limits. The groups of north-striking and -dipping nodal planes were preferred because they are most consistent with the late Quaternary faults identified by Ziony and Yerkes (1985). 


\section{Seismotectonic Model}

The focal mechanisms and the results of the stress inversion suggest that the tectonic deformation along the north and south segments of the NIF is controlled by different stress fields. The stress field to the south has a vertical intermediate principal stress that results in mostly strike-slip faulting with a few cases of normal faulting. The stress field along the north segment has a vertical minimum principal stress and causes an even mixture of strike-slip and reverse faults. This variation in type of faulting may be related to either a westward stepping over of the north segment relative to the south segment or to an increase in both north-south and east-west horizontal stresses adjacent to the southern margin of the Transverse Ranges.

The north segment of the NIF steps to the west across the Dominguez and Rosecrans Hills. The north segment also trends more northerly than the south segment by $10^{\circ}$ to $15^{\circ}$ of azimuth. The contours of depth to basement in the Los Angeles basin, which are shown in Figure 12, show an increase in depth where the

\section{LOS ANGELES BASIN}

\section{Depth to Basement in $1000 \mathrm{ft}$. \\ Seismicity $1973-1985$}

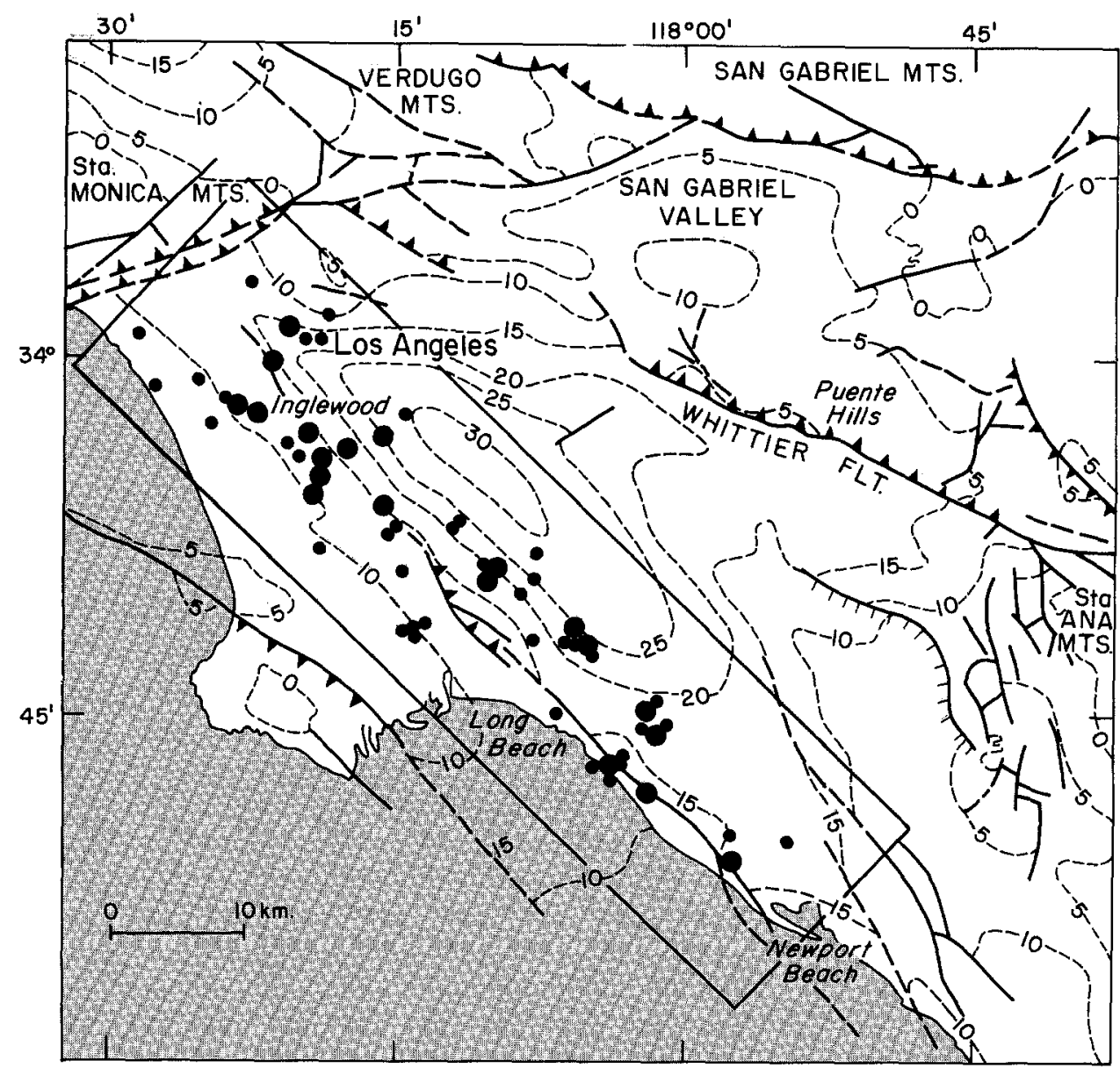

FIG. 12. Map of the Los Angeles basin showing depth to basement in $1000 \mathrm{ft}$ contours (Yerkes et al., 1965). Relocated hypocenters (1973 to 1985) along the NIF are also shown. 
north segment steps to the west. As the crustal block to the west of the fault moves in a $\mathrm{N} 35^{\circ} \mathrm{W}$ direction (as a part of the Pacific plate), it collides at the west offset with the crustal block to the east of the fault. Hence, the north segment is being compressed between the left step around the Dominguez Hills. In addition to the focal mechanisms that show reverse faulting, the compression is expressed in the Dominguez, Rosecrans, and Baldwin Hills as uplift along the fault. This model, however, would predict that a strike-slip stress field existed to the north of the Baldwin Hills since the zone of compression and uplift would have a limited spatial extent. This is not observed and to the contrary the compressional deformation appears to increase toward the north.

An increase in north-south horizontal stress and east-west horizontal stress can make east-west compression comparable in size to vertical stress. This stress state can also cause both reverse faulting as well as uplift along the fault. Such an increase in horizontal stress may be related to movement of California west of the San Andreas fault around the big bend region of the San Andreas. Weldon and Humphreys (1986) presented a model where most of California west of the San Andreas (including the Los Angeles basin) is moving with a velocity parallel to the San Andreas fault through the Transverse Ranges, which is not parallel to the velocity of the Pacific Plate. In their model, the Central Transverse Ranges are converging toward $\mathrm{N} 25^{\circ} \mathrm{W}$ with a velocity of $3 \mathrm{~mm} / \mathrm{yr}$ as they move laterally around the big bend of the San Andreas. Moreover, the Los Angeles basin block in their model is moving in a direction of $\mathrm{N} 18^{\circ} \mathrm{W}$ toward the Central Transverse Ranges. This difference in direction of motion of these crustal blocks may be sufficient to create an increase in horizontal stresses along the north segment of the NIF. A different manifestation of increased east-west horizontal stress is the left oblique reverse motion along the southern margin of the Transverse Ranges (Ziony and Yerkes, 1985). The mechanical coupling between the Central Transverse Ranges and the Los Angeles basin thus may modify the state of stress in the northern part of the basin such that a transition zone of deformation from strike-slip to reverse faulting is formed.

\section{EaRThQuake Potential}

The 1933 Long Beach earthquake $\left(M_{L}=6.3\right)$ demonstrates that the NIF is capable of generating moderate-sized or larger damaging earthquakes. The 1933 Long Beach main shock ruptured the fault from Newport Beach to Signal Hill, over a distance of 30 to $40 \mathrm{~km}$ (Hileman et al., 1973). Recently, Ziony et al. (1985) have suggested that an earthquake of moment magnitude 6.5 could rupture the north segment between the end of the 1933 rupture and the Santa Monica fault. An earthquake of that size could cause strong ground shaking in the Los Angeles basin lasting for approximately 10 to $15 \mathrm{sec}$ and could trigger liquefaction near the coast and landslides in upland areas. Moreover, both primary and secondary surface rupture is predicted by Ziony et al. (1985) along the Avalon-Compton fault, Potrero fault, and Inglewood fault (see also Figure 1).

The distribution of epicenters in Figure 7 suggests that smaller branch faults striking subparallel to the trace of the main fault zone are also seismically active. Along the north segment of the NIF both the mapped surface traces and the seismicity form a diffuse zone, approximately 5 to $10 \mathrm{~km}$ wide. This indicates that the geometrical configuration of the north segment of the NIF is complex, and a future moderate-sized event may result in seismogenic slip on several subparallel but discontinuous fault strands. 
In Long Beach, the epicenters are offset 4 to $6 \mathrm{~km}$ to the east of the main fault trace and appear to coincide with the subsurface Los Alamitos fault (Figure 7). Since estimates of the late Quaternary slip rate of the NIF range from 0.5 to approximately $1 \mathrm{~mm} / \mathrm{yr}$ (Ziony and Yerkes, 1985) and the slip of the 1933 Long Beach earthquake was 0.31 to $0.46 \mathrm{~m}$ (Woodward-Clyde Consultants, 1979), the repeat time of such an earthquake is on the order of several hundred years. Hence, a repeat of the 1933 Long Beach earthquake is not likely to take place for a few hundred years, and the seismicity along the Los Alamitos fault may simply be a result of the strain accumulation or adjustment following the 1933 event.

\section{Discussion}

The late Quaternary geologic slip rate of the NIF is estimated to be about $1 \mathrm{~mm} /$ yr (Ziony and Yerkes, 1985). The rate of seismicity, however, is relatively high when compared to the activity of other Quaternary faults in the Los Angeles basin with similar slip rates (Yerkes, 1985). For instance, less seismicity is observed around the Palos Verdes fault and the Santa Monica-Raymond Hills fault than around the NIF (Figure 2) even though they have similar slip rates. This apparent variation in spatial distribution of seismicity may reflect differences in fault mechanics or simply reflect the relatively short time span for historical and instrumental records in southern California.

The depth distribution of small earthquakes (Figure 8) around the NIF coupled with the average heat flow (Lachenbruch et al., 1985) suggests that the brittleductile transition zone is at the same depth as elsewhere in southern California (Sibson, 1984). The depth distribution of seismicity along the NIF falls between the depth distributions of seismicity for the Imperial Valley and the Peninsular Ranges reported by Doser and Kanamori (1986). The apparent high rate of seismicity thus does not seem to be caused by unusual thermomechanical conditions of failure along the NIF.

Evidence from cores taken from deep boreholes in oil fields along the NIF zone provide information about the basement rocks. To the south of Seal Beach oil field, the Catalina Schist abuts with the crystalline basement of the Peninsular Ranges (Yeats, 1973). To the north of Seal Beach oil field, a wedge shape sliver of basement rocks containing actinolite-bearing greenschist and serpentine separates the Catalina Schist and the crystalline basement with increasing separation to the north (Yeats, 1973). These basement rocks that are retrograde plutonic rocks differ both from the Catalina Schist (Franciscan) basement found to the southwest and the crystalline Peninsular Ranges basement found to the east (Yeats, 1973). Hence, the NIF may not form the basement boundary in the Los Angeles basin between Catalina Schist and crystalline basement. The actual basement boundary probably strikes due north from the Seal Beach oil field (Yeats, 1973). This variation in crustal composition across the NIF may be similar but less severe than variations in rock types along, for instance, some sections of the San Andreas fault.

Additional quantitative comparisons of the rate of seismicity, geologic slip rates, and mechanical behavior of other faults in the Los Angeles basin are needed. For instance, studies of seismicity along the Palos Verdes fault and the WhittierElsinore faults would better define the seismic potential of these northwest-striking predominantly strike-slip faults. These faults (including the NIF) contribute significantly to seismic hazards in the Los Angeles basin, since they may accommodate 10 to 15 per cent of the relative plate motion between the North American and Pacific plates (e.g., Weldon and Humphreys, 1986). While the seismic hazard is 
higher along the southern San Andreas fault, where $24.5 \mathrm{~mm} / \mathrm{yr}$ (of a total rate of relative plate motion of $56 \mathrm{~mm} / \mathrm{yr}$ ) of motion are accommodated, the potential for property damage and loss of life is much greater in the densely populated metropolitan area of Los Angeles.

\section{CONCLUSIONS}

Small earthquakes $\left(2.5 \leqq M_{L}<3.8\right)$ occur at a steady rate of 2 to 9 events per year along the entire NIF. The distribution of relocated hypocenters (1973 to 1985) shows an improved correspondence to mapped traces of late Quaternary fault segments of the NIF. A diffuse trend of seismicity is observed from Dominguez Hills to the Santa Monica fault in the north. An almost linear trend of seismicity is observed along the trace of the subsurface Los Alamitos fault to the east of Long Beach. The depth distribution of earthquakes shows that most earthquakes occur at depths from 6 to $11 \mathrm{~km}$. A new preliminary velocity model for the western Los Angeles basin shows significantly lower velocities down to depths of 12 to $16 \mathrm{~km}$ than the corresponding velocities observed outside the basin, which suggests a basement of Catalina Schist. The focal mechanisms of 39 small earthquakes and the results of the corresponding stress inversion show that different stress fields operate along the north and south segments of the NIF. The north segment has the minimum principal stress vertical (which is consistent with reverse faulting) while the south segment has the intermediate principal stress vertical, indicating strikeslip faulting. The reverse faulting suggests that a transition zone of mostly compressive deformation exists between the Los Angeles basin block and the Central Transverse Ranges.

\section{ACKNOWLEDGMENTS}

I thank L. M. Jones, J. I. Ziony, and G. V. Saldivar for critical reviews. A. J. Michael made copies and documentation of his stress inversion programs available. W. L. Ellsworth and R. S. Cockerham provided advice and copies of the VELEST programs. L. M. Jones and L. K. Hutton made copies of the CIT/USGS southern California network data available. G. V. Saldivar assisted with rechecking the USC arrival time data. This research was supported by U.S. Geological Survey Grants 14-08-0001-G983 and G1158 and U.S. Geological Survey Contract 14-08-0001-A0264. The USC seismic network is partially supported by the THUMS Long Beach Company. The figures were drafted by J. Dodds and the manuscript typed by S. Turnbow.

\section{REFERENCES}

Angelier, J. (1984). Tectonic analysis of fault slip data sets, J. Geophys. Res. 89, 5835-5848.

Angelier, J., A. Tarantola, B. Valette, and S. Manoussis (1982). Inversion of field data in fault tectonics to obtain the regional stress. I. Single phase fault populations: a new method of computing the stress tensor, Geophys. J. R. Astr. Soc. 69, 607-621.

Barrows, A. G. (1974). A review of the geology and the earthquake history of the Newport-Inglewood structural zone, southern California, Calif. Div. Mines and Geology Spec. Rept. 114, 115 pp.

Benioff, H. (1938). The determination of the extent of faulting with application to the Long Beach earthquake, Bull. Seism. Soc. Am. 28, 77-84.

Binder, R. W. (1952). Engineering aspects of the 1933 Long Beach earthquake, in Proceedings of Symposium on Earthquake and Blast Effects on Structures, Earthquake Engineering Research Institute and University of California, Los Angeles, California, 186-211.

Bonilla, M. G., R. K. Mark, and J. J. Lienkaemper (1984). Statistical relations among earthquake magnitude, surface rupture length, and surface fault displacement, Bull. Seism. Soc. Am. 74, 23792412 .

Crosson, R. S. (1976). Crustal structure modeling of earthquake data. I. Simultaneous least squares estimation of hypocenter and velocity parameters, J. Geophys. Res. 81, 3036-3046.

Doser, D. I. and H. Kanamori (1986). Depth of seismicity in the Imperior Valley region (1977-1983) and 
its relationship to heat flow, crustal structure, and the October 15, 1979 earthquakes, J. Geophys. Res. 91, 675-688.

Ellsworth, W. L. (1977). Three-dimensional structure of the crust and mantle beneath the islands of Hawaii, Ph.D. Thesis, Massachusetts Institute of Technology, Cambridge, Massachusetts, $327 \mathrm{pp}$.

Gephart, J. W. and D. W. Forsyth (1984). An improved method for determining the regional stress tensor using earthquake focal mechanism data: application to the San Fernando earthquake sequence, J. Geophys. Res. 89, 9305-9320.

Given, D. D. and C. L. Koesterer (1983). Station arrival data for a quarry blast on Santa Catalina Island, California, U.S. Geol. Surv., Open-File Rept. $83-462,12$ pp.

Guptill, P. D. and E. G. Heath (1981). Surface faulting along the Newport-Inglewood zone of deformation, Calif. Geol. 34, 142-148.

Hadley, D. and H. Kanamori (1977). Seismic structure of the Transverse Ranges, California, Geol. Soc. Am. Bull. 88, 1469-1478.

Hart, E. W. (1980). Fault-rupture hazard zones in California, Calif. Div. Mines Geol. Spec. Publ. 42, 25 pp.

Hearn, T. M. (1984). Pn travel times in southern California, J. Geophys. Res. 89, 1843-1855.

Hileman, J. A., C. R. Allen, and J. M. Nordquist (1973). Seismicity of the southern California region 1 January 1932 to 31 December 1972, Seismological Laboratory, California Institute of Technology, Pasadena, California, $387 \mathrm{pp}$.

Johnson, C. E. (1979). CEDAR-An approach to the computer automation of short-period local seismic networks, Ph.D. Dissertation, California Institute of Technology, Pasadena, California, $142 \mathrm{pp}$.

Johnson, C. E. (1983). CUSP-Automated processing and management for large regional seismic networks, Earthquake Notes 54, 13.

Klein, F. W. (1985). User's guide to HYPOINVERSE, a program for VAX and PC350 Computers to Solve for earthquake locations, U.S. Geol. Surv., Open-File Rept. 85-515, 24 pp.

Lachenbruch, A. H., J. H. Sass, and S. P. Galanis, Jr. (1985). Heat flow in southernmost California and the origin of the Salton trough, J. Geophys. Res. 90, 6709-6736.

Malin, P. E., M. H. Gillespie, P. C. Leary, and T. L. Henyey (1981). Crustal structure near Palmdale, California, from borehole-determined ray parameters, Bull. Seism. Soc. Am. 71, 1783-1803.

Michael, A. J. (1984). Determination of stress from slip data: faults and folds, J. Geophys. Res. 89, $11,517-11,526$.

Millikan, R. A. (Chairman) (1933). Earthquake hazard and earthquake protection, Joint Technical Committee on Earthquake Protection, June 1933, Los Angeles, California, 13 pp.

Norris, R., C. E. Johnson, L. M. Jones, and L. K. Hutton (1986). The bulletin of the southern California seismic network, U.S. Geol. Surv., Open-File Rept. 86-96, 32 pp.

Real, C. R. (1977). Seismicity and tectonics of the Santa Monica-Hollywood-Raymond Hill fault zone and northern Los Angeles basin, Los Angeles County, California, in Transverse Ranges, U.S. Geol. Surv. Profess. Paper (in press).

Reasenberg, P. and D. Oppenheimer (1985). FPFIT, FPPLOT and FPPAGE: Fortran computer programs for calculating and displaying earthquake fault-plane solutions, U.S. Geol. Surv., Open-File Rept. $85-739,46$ pp.

Richter, C. F. (1958). Elementary Seismology, W. H. Freeman and Company, San Francisco, California, $768 \mathrm{pp}$.

Roecker, S. W. (1981). Seismicity and tectonics of the Pamir-Hindu Kush region of Central Asia, Ph.D. Thesis, Massachusetts Institute of Technology, Cambridge, Massachusetts, $297 \mathrm{pp}$.

Roecker, S. and W. L. Ellsworth (1978). VELEST, Fortran Program, U. S. Geological Survey, Menlo Park, California.

Sibson, R. H. (1984). Roughness at the base of the seismogenic zone: contributing factors, J. Geophys. Res. 89, 5791-5799.

Spudich, P. A. and S. H. Hartzell (1985). Predicting earthquake ground-motion time-histories, in Evaluating Earthquake Hazards in the Los Angeles Region, J. I. Ziony, Editor, U.S. Geol. Surv. Profess. Paper 1360, 249-260.

Taber, S. (1920). The Inglewood earthquake in southern California, June 21, 1920, Büll. Seism. Soc. Am. $10,129-145$.

Teng, T. L., C. R. Real, and T. L. Henyey (1973). Microearthquakes and water flooding in Los Angeles, Bull. Seism. Soc. Am. 63, 859-875.

Weldon, R. and G. Humphreys (1986). A kinematic model of southern Californiä, Tectonics 5, 33-48.

Wilcox, R. E., T. P. Harding, and D. R. Seely (1973). Basic Wrench Tectonics, Am. Assoc. of Petrol. Geol. Bull. 57, 74-96. 
Wood, H. O. (1933). Preliminary report on the Long Beach earthquake, Bull. Seism. Soc. Am. 23, 4356.

Woodward-Clyde Consultants (1979). Report on the evaluation of maximum earthquake and site ground motion parameters associated with the Offshore Zone of Deformation, San Onofre Nuclear Generation Station, Los Angeles, California, Report prepared for Southern California Edison, 56 pp.

Yeats, R. S. (1973). Newport-Inglewood Fault Zone, Los Angeles Basin, California, Am. Assoc. Petrol. Geol. Bull. 57, 117-135.

Yerkes, R. F. (1985). Geologic and seismologic setting, in Evaluating Earthquake Hazards in the Los Angeles Region, J. I. Ziony, Editor, U.S. Geol. Surv. Profess. Paper 1360, 25-41.

Yerkes, R. F., T. H. McCulloh, J. E. Schoellhamer, and J. G. Vedder (1965). Geology of the Los Angeles basin, California--An introduction, U.S. Geal. Surv. Profess. Paper 420-A, A1-A57.

Ziony, J. I. and R. F. Yerkes (1985). Evaluating earthquake and surface-faulting potential, in Evaluating Earthquake Hazards in the Los Angeles Region, J. I. Ziony, Editor, U.S. Geol. Surv. Profess. Paper $1360,43-91$.

Ziony, J. I., C. M. Wentworth, J. M. Buchanan-Banks, and H. C. Wagner (1974). Preliminary map showing recency of faulting in coastal southern California, Map MF-585, U.S. Geological Survey, Menlo Park, California.

Ziony, J. I., J. F. Evernden, T. E. Fumal, E. L. Harp, S. H. Hartzell, W. B. Joyner, D. K. Keefer, P. A. Spudich, J. C. Tinsley, R. F. Yerkes, and T. L. Youd (1985). Predicted geologic and seismologic effects of a postulated magnitude 6.5 earthquake along the northern part of the Newport-Inglewood zone, in Evaluating Earthquake Hazards in the Los Angeles Region, J. I. Ziony, Editor, U.S. Geol. Surv. Profess. Paper 1360, 415-441.

DEPaRTMENT OF Geological SCIENCES

UNIVERSITY OF SOUTHERN CALIFORNIA

Los Angeles, California 90089-0741

Manuscript received 20 June 1986 